\title{
"Il Futuro Ha un Cuore Antico" Archaeology in Italy: a Brief Outline of a Long History
}

\author{
Monica De Simone \\ Rome, ITALY \\ Laurea, Sapienza University of Rome, Italy, 1994 \\ Diploma of Specialization in Archaeology-Classical Archaeology, \\ Sapienza University of Rome, Italy, 2000

\begin{abstract}
A Thesis presented to the Graduate Faculty
of the University of Virginia in Candidacy for the Degree of

Master of Arts
\end{abstract}

McIntire Department of Art

University of Virginia

July, 2013 


\section{Contents}

Il futuro ha un cuore antico: A brief outline of a long history ............................................... 2

1. Humanism and Renaissance (XV-XVI cent.): the Discovery of the Classical

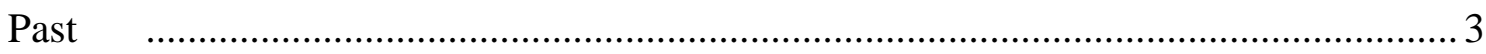

2. Antiquarians, Academies, and Erudition (XVII -XVIII centuries) ................................ 7

3. The XIX Century: the Birth of Archaeology as a Discipline, the Unification of Italy, and the German Influence ........................................................................ 10

4. The Fascist Era: Archaeology at the Service of Power............................................. 19

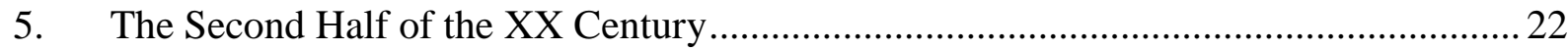

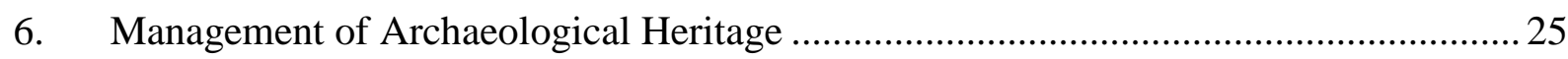

7. Public Archaeology in Italy: Between Emergency and Prevention ............................... 37

8. The Debate about the Professional Archaeologist and the Reorganization of

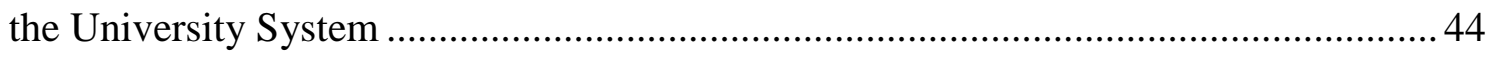

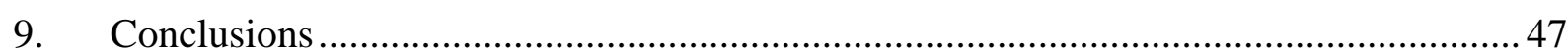

Appendix 1. Important Italian Archaeologists (from 1861) ................................................ 49

Appendix 2. The Structure of MiBAC (Ministry of Cultural Heritage and Tourism) ............. 50

Appendix 3. Important Laws and Regulation Concerning Cultural Heritage in Italy..............55

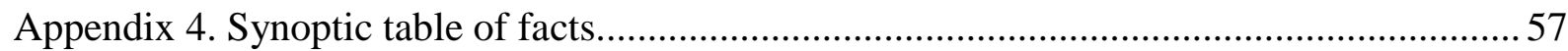

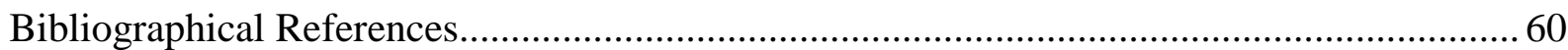




\section{Il futuro ha un cuore antico: A brief outline of a long history *}

Time and Space are the two main categories through which a history of Italian archaeology can be presented. The present continuously changes the way scholars approach different issues. Italy is one of the most important regions in terms of classical - and not only classical - archaeology. A long history of peoples, towns, villages, and countryside, for some only a "geographical expression," ${ }^{1}$ for others a historical melting pot of different cultures, and finally a country, Italy has always been a main actor on the archaeological stage. Both because of its significant remains and thanks to its important scholars, archaeology in Italy is everywhere. Who were these scholars and main characters? Who are they now? How did they play their role and how do they still? Which were the internal elements that influenced and changed the discipline, which the external? Which are now the main issues and the future challenges?

The attempt here is to offer an overview of what archaeology has been, is, and will be in Italy, through a brief sketch of its protagonists and their contexts (e.g., Boni, Calza, Bianchi Bandinelli, Pallottino, Lamboglia, Carandini). The present paper outlines the main aspects of the Italian world of classical archaeology, from 'prehistory' to our time, briefly summarizing

${ }^{*}$ Il futuro ha un cuore antico (The future has an ancient heart) is the title of a novel by Carlo Levi, 1956. Here it is used as a vivid image of the continuity and the meaning of History.

${ }^{1}$ The Austrian minister Metternich (1773-1859) looked at Italy as a simple “geographical expression,” indicating the lack of a central power and of a cultural identity at his time. The same image has been often exploited in order to complain about the absence of the Nation concept. It is important to rethink such a sentence with present eyes, now that European identity and local autonomies draw in opposite directions. The validity of Italy as a multifaceted unit is undeniable. In spite of and perhaps because its plurality the Bel Paese dates back to the Roman Empire, and its citizens, whether they want it or not, have a strong feeling of history. 
aspects concerning large-scale excavations, institutions, laws, museums and academies, universities and research centers, associations, and the way this whole world affects the wider audience. The three most recent keywords today in Italy, Ricerca, Tutela, and Valorizzazione ${ }^{2}$, can be acknowledged, at least as veiled concepts, since the very beginning of interest in antiquities. This characteristic is typical of Italy, due to the very special nature of its cultural heritage.

In order to understand the development of the topic from the initial attention to antiquities to the modern discipline, ${ }^{3}$ it is worth looking at the rediscovery of the Classical World during the XV century A.D.

\section{Humanism and Renaissance (XV-XVI cent.): the Discovery of the Classical Past}

At this time Italy was not yet a unified country, but many small states scattered through the peninsula. Intellectuals did not belong to a specific region; they traveled around and spread their knowledge. Many were at the same time thinkers, artists, poets, and politicians and offered their services to the ruler. ${ }^{4}$ The studia humanitatis used classical literature as their springboard, but very soon they expanded to include classical art and monuments. This 'new

${ }^{2}$ Research, Long-term Protection, and Public access are now the three main themes on the stage, a sort of a magic spell in any conference or paper title. It is worthy to notice that an internet inquiry in Google, with these three words in Italian, produces about 2,320,000 results (87,500 as "ricerca, tutela e valorizzazione").

${ }^{3}$ The historical summary is based mainly on Pallottino 1958, Pallottino 1968, Bianchi Bandinelli 1976, Carandini 1991, Pucci 1993, Barbanera 1998, Barbanera 2000, integrated with information available through the main websites of the Italian Archaeological Institutions.

${ }^{4}$ The intellectuals were at the service of the power-holders, covering many different fields, not only cultural, but also political. Lorenzo Valla, Flavio Biondo and Pirro Ligorio worked for the Popes, and not only for them. 
discovery' of the Classical world includes the acknowledgement of the past as a different era, but still as an ideal model to look at and to emulate. ${ }^{5}$

The humanist Lorenzo Valla (1405-1457), considered the father of philology, wrote De falso credita et ementita Constantini donatione declaratio in $1440,{ }^{6}$ in which he stated that the text of the Donation of Constantine was a forgery. The new perspective, brought with his method of analysis, challenged the medieval tradition, urging the recovery of the original classical material. The assumption involved the need for a direct contact with the ancient past, which was also available through monuments and works of art. Artists drew and took their inspiration from the ancient remains. Inscriptions or statues, in fact, had suffered fewer modifications than transmitted texts, and seemed to be more reliable in terms of authenticity. The next step, taken by the one who is considered the first historian-topographer, Flavio Biondo (Forlì 1392-Rome 1463), acknowledged the connection between texts and artifacts. In his works, ${ }^{7}$ which became the basis for any further topographical study, there is a combination of literary evidence and observations of surviving remains.

${ }^{5}$ This assumption is valid both for poets and artists. Just two examples among many: the figure of the humanist and poet Angelo Poliziano (1454-1494), who was also professor of Greek and Latin Literature in Florence, and his literary production; the discovery of paintings of the Domus Aurea and the fortune of the grotesque style.

${ }^{6}$ Valla, 1927; Coleman 1922. Electronic version of the book is also available, with the Latin text and translated in English at http://history.hanover.edu/texts/vallapart2.html.

${ }^{7}$ Roma Instaurata (1446); Italia Illustrata (1448-1453); Roma Triumphans (1457-1459). For the first two works see the edition published in 1527 in Turin, Blondi Flauii De Roma instaurata libri tres ad Eugenium, iiii, pontificem maximum. Blondi Flauii de Italia illustrata, and for the third work the edition published in 1531 in Basil, Blondi Flavii De Roma triumphante libri decem. 
Inspired by the monuments still standing in his hometown, such the Arch of Trajan, the antiquarian-merchant Ciriaco de’ Pizzicolli from Ancona went further, ‘discovering' Greece. Born in Ancona (in the Papal State) in 1391, he was an eclectic self-taught man who, during his commercial traveling, visited many sites in Greece, collecting inscriptions, manuscripts, and antiquities. He copied thousands of inscriptions in the Eastern Mediterranean and in Italy. Because of his reliability and consistency he is considered the father of epigraphic studies. He was convinced that "archaeological monuments [i.e., inscriptions] provide a more direct testimony of antiquity than the literary tradition." ${ }^{8} \mathrm{He}$ never published a synthesis of his extensive research, but, relying on his surviving notes, other scholars published the material long after his death. ${ }^{9}$ He served under the Papal State, the Lordship of Florence and the Duchy of Milan, where he died, in Cremona in 1452, only one year before the conquest of Constantinople by the Turks (1453), which practically made the East Mediterranean inaccessible to western travelers.

As soon as interest developed in Roman and Greek works of art, the phenomenon of collecting antiquities increased, especially among the power-holders. In 1471, Pope Sixtus IV gave back to the people of Rome as a donation some bronze statues kept in his Lateran Palace. These statues had been visible since antiquity and they were considered part of the identity of

${ }^{8}$ Rowe 1965, 6.

9 Epigrammata reperta per Illyricum a Kyriaco (Rome 1664) and Itinerarium (Florence, 1742). For the Epigrammata, see the edition published in 1747 in Rome: Inscriptiones, seu Epigrammata graeca et latina reperta per Illyricum a Cyriaco Anconitano apud Liburniu, designatis locis, ubi quaeque inventa sunt cum descriptione itineris. For the Itinerarium see the edition published in 1742 in Florence: Kyriaci Anconitani Itinerarium nunc primum ex ms. cod. in lucem erutum ex bibl. illus. clarissimique baronis Philippi Stosch. Editionem recensuit, animadversionibus, ac praefatione illustravit, nonnullisque ejusdem Kyriaci epistolis partim editis, partim ineditis locupletavit Laurentius Mehus. See also Hülsen 1907. 
the city of Rome and of its inhabitants. Among these statues, there were the famous She-wolf; the head, a hand and the globe of the colossal statue of Constantine; the Camillus, and the Spinario. The statues were then moved from the Lateran Palace into what can be considered the first archaeological museum in the world, the Conservators' Palace on the Capitoline hill. This constituted the creation of the first nucleus of the Capitoline Museums, which for 150 years were enriched, and finally reorganized and officially opened to the public in 1734 by Pope Clemens XII. ${ }^{10}$ The symbolic importance of those statues was in some way recognized also by Napoleon, when he avoided choosing them for his plunder, in order to stay away from the accusation of 'thief of the people.' 11

In 1505 Pope Julius II created the Belvedere Museum in his Palace at the Vatican, which represented the foundation of the nucleus of the Vatican Museums. ${ }^{12}$ In 1506 , the statue of the Laocoon was recovered on the Oppian hill. Because of the richness of arts in Rome, the Popes had to realize that a policy was mandatory. In 1534 Pope Paulus III created the position of Director of the Commission for Antiquities (Commissario delle Antichità). ${ }^{13}$ The eagerness for ancient masterpieces of art increased when private collections were also being created and soon the treasure hunt paralleled the humanist's interest. Between these two issues stands the very eclectic character of Pirro Ligorio. Born in Naples in 1513, he was an architect, painter,

${ }^{10}$ For a brief history of the Capitoline Museums and the collections, and for a virtual visit, see the official web site at: http://www.museicapitolini.org/it/index_msie.htm. It is noteworthy to mention that the Capitoline Museums remain in a close relationship with the City of Rome, depending from the Sovraintendenza Comunale ai Beni Culturali del Comune di Roma (see Appendix 1).

11 Pucci 1993, 21-2.

12 For a brief history of the Vatican Museums and collections, see the official web site at: http://mv.vatican.va/2_IT/pages/z-Info/MV_Info_NotizieStoriche.html.

\footnotetext{
13 Barbanera 1998, 7.
} 
antique dealer and art writer. He worked in Rome for the Cardinal Ippolito d'Este and then for the Popes Paulus IV and Pius IV. Under the last he became the main architect of Saint Peter's Basilica, as the successor of Michelangelo. He is famous for popularizing the grotesque style, imitating the paintings of the Domus Aurea. He also conducted extensive excavations in the Roman Forum and, on behalf of the D'Este and Farnese noble families, at Hadrian's Villa near Tibur. He wrote extensively on antiquities, but his reputation has been controversial, because the authenticity of his knowledge was challenged, and because his activities as an antique dealer encouraged him to fake ancient works, especially in the last years of his life. Nevertheless his copious writings are still a precious account. ${ }^{14}$ In the second half of XVI cent., probably as a collateral effect of the Counter-reformation, a new interest in Christian antiquities arose, thanks to Onofrio Panvinio (1530-1568) and Antonio Bosio (1576-1629), who explored the catacombs. ${ }^{15}$

\section{Antiquarians, Academies, and Erudition (XVII -XVIII centuries)}

In the XVII century, also due to the Catholic reaction to the Protestant Reform, there is a sort of detachment from the Classical past. The new political situation and the different role of the intellectuals in everyday life led to a period of seclusion into the Academies in the

\footnotetext{
${ }^{14}$ He created a sort of encyclopedia of the antique, with his handwritten volumes, now preserved in the
} National Library of Naples, in the State Archive of Turin (30 volumes), in Rome, Ferrara, Paris, and Oxford (the State Archive of Turin hosted the exhibit "Pirro Ligorio. L'opera manoscritta di un erudito rinascimentale," Turin, May 24-30, 2004). Most of the material collected by Pirro Ligorio was printed living the author; see, for instance, Pirro Ligorio, Libro di M. Pyrrho Ligori napolitano, delle antichità di Roma: nel quale si tratta de’ circi, theatri \& anfitheatri: con le paradosse del medesimo auttore, quai confutano la commune opinione sopra vari luoghi della città di Roma, Venice 1553.

${ }^{15}$ Coche de La Ferté 1958, 558. 
XVIII century. The XVII and XVIII centuries mark a time of catalogues, scholars' fights, interpretations, and collections of sources and materials. Interest concentrated on historicaltopographical dissertations, often attempting to recognize scanty ruins in historical sites. Raffaele Fabretti (1618-1700) is one of the outstanding figures of this age and he well represents it. Since he worked for the Papal State, as a diplomat and as a treasurer, he had the chance to conduct excavations in the catacombs and to engage in various topographical studies. His main work concerns roman aqueducts ${ }^{16}$ and is still used as a reference.

Archaeology as a discipline was not yet born, since at this point methodology and analytical procedures had not yet developed. It was a primitive enthusiasm which motivated both collectors and erudite scholars. The efficient cataloguing and reproducing of artifacts (drawings, copies, etc.), however, have an inestimable value, since much of the data would have been completely lost if it had not been recorded. The major change of the XVIII century consisted of the discovery and subsequent excavations of Herculaneum and Pompeii in the kingdom of Naples, under Carlo III di Borbone. Herculaneum was discovered in 1709 and excavations began in 1738; only ten years later the Borbone family decided to start digging at Pompeii and in 1754 at Stabiae. Extensive excavations also flourished in Etruscan necropoles (Tarquinia, Vulci, Cerveteri), in the Papal State (Palatine Hill, 1720-1727; Roman Forum, 1778; Via Appia, 1780; Hadrian’s Villa and Ostia (end of XVIII century). At the same time many Academies were born, following the enthusiasm of the discoveries (Accademia Etrusca di Cortona, 1727; Società Colombaria in Florence, 1735; Reale Accademia Ercolanese, 1738; Accademia di Antichità Profane [or Romane] in Rome, ${ }^{17}$ 1740). Collectors were doubtless

\footnotetext{
${ }^{16}$ Fabretti 1680.

${ }^{17}$ The Accademia di Antichità Profane became the Accademia Romana di Archeologia in 1810 and
} earned the title of Pontificia in 1829. It is still existing and operating. 
amazed at the new availability of works of art and were urged to preserve ancient sites from spoliation. By this time Italy had become the most important destination for the Grand Tour. Many other travelers had preceded Goethe's journeys in Italy (1786-1788, 1790), ${ }^{18}$ since Greece was not yet a safe destination. In 1755 Carlo III di Borbone issued laws in order to prevent illicit excavations and exportation of antiquities. The king may have acted to protect his personal treasure, but it is undeniable that a new awareness was emerging. The antiquities were acknowledged to be the property of the state, for public utility. ${ }^{19}$ The abundance of laws and regulations is a signal of consciousness, but very often they were inefficient and not taken seriously. In addition, the lack of tools for preventing illicit trade and excavations made such laws completely useless. The recognized importance of every single object in its context is a concept of the early XIX century, but this sensibility was undeniably due to the discovery of the Vesuvian towns' unique conditions. ${ }^{20}$

The second half of the XVIII century is characterized by the influence of Winckelmann with his approach to the study of Greco-Roman antiquities as art history. ${ }^{21}$ Winckelmann arrived in Rome in 1755 and later became Conservator of the Antiquities of Rome. He attempted to create a chronological development of ancient art with a stylistic criterion. Winckelmann's influence was partially overshadowed by the new trend of philological

${ }^{18}$ J.W. Goethe (1749-1832) published in 1816 his Italiänische Reise, an autobiographical work on his first trip; see Goethe 1970; 1997.

${ }^{19}$ An attention to the 'audience' is recognizable also in the openings of museums to the public (for instance: the official re-opening of the Capitoline Museum, 1734; the Museum of Inscriptions in Verona, 1720/1754; the Biscari Museum in Sicily, 1758). Pucci 1993, 47, 92.

${ }^{20}$ The antiquarian Scipione Maffei (1675-1755) wished Pompeii would become an open air museum, in order to preserve objects in their context; see Pucci 1993, 92.

${ }^{21}$ Winckelmann, 1764. 
archaeology, whose first representative can be considered Ennio Quirino Visconti. Visconti is the main figure of the end of the century. Son of the Director of Antiquities in Rome, he became Conservator at the Capitoline Museums and later, in 1799, when he followed Napoleon to France, was put in charge as Curator of Antiquities at the Louvre. Methodical, educated in classical culture, and gifted with an extraordinary memory, he recognized that most of the Roman statues were copies of Greek ones. This assumption led him to the identification of famous masterpieces, such as the Discobolus of Myron, the Aphrodite Knidos of Praxiteles, and the Eirene and Ploutos of Kephisodotos. Sadly his generation of Italian erudite scholars and antiquarians failed to create a school, an educational system which would have transmitted their knowledge and their methods.

\section{The XIX Century: the Birth of Archaeology as a Discipline, the Unification of Italy, and the German Influence}

Romanticism and its renewed interest in history, combined with Winckelmann's influence, generated awareness of the value of preserving the past from despoliation. At the beginning of the XIX century, Carlo Fea (1753-1836) was Director of the Commission for Antiquities (Commissione alle Antichità) in the Papal State and he was also the editor of Winckelmann's works. ${ }^{22}$ His efforts concerning preservation produced the Chirographus of 1802, a set of regulations and laws issued by the Pope in order to protect antiquities. A more detailed organization was developed in order to take care of Roman antiquities (Commissione di Belle Arti, with several internal divisions). In 1820 a second major Edict followed (Editto Pacca), which became a fundamental part of the later Italian policy on cultural heritage. On the 21st of April 1829 (the Parilia day, the traditional 'birthday' of Rome), the Istituto di

\footnotetext{
${ }^{22}$ Winckelmann, 1783-4.
} 
Corrispondenza Archeologica (Institute of Archaeological Correspondence) was founded in Rome. Formerly supranational, the Institute was completely under the Prussian government in 1871, and finally became the German Archaeological Institute (DAI).

In the Kingdom of Naples, paintings and ancient everyday-life objects from Herculaneum and Pompeii were copious and for the most part they were moved to the Borbone's Museum in Naples. In 1807, a law attempted to fight illicit exportation and, in 1839, an edict stated that if an object was removed from its context and brought to the museum, it had to be substituted by a copy. ${ }^{23}$

The first half of the century was dominated by old-fashioned, but still excellent, antiquarians and topographers (Carlo Fea, 1753-1836; Bartolomeo Borghesi 1781-1860; Antonio Nibby, 1792-1839; and Luigi Canina, 1795-1856). The fragmented political situation of Italy did not allow the creation of a solid educational system, which was developing in Germany with regard to philology. Universities in the Italian states had chairs of antiquities, but they were held by antiquarians with traditional attitudes. Individuals were outstanding, but they did not produce a school of followers. However, excavations and research projects were becoming more and more extensive and, in a certain way, systematic.

When Italy became a unified country, ${ }^{24}$ management of archaeological heritage arose along with many other organizational issues. Many correlated problems appeared: lack of funding and capable people for administration; no homogeneity of the former states on the subject of structures and regulations concerning antiquities; weakness and backwardness of

${ }^{23}$ Barbanera 1998, 9; Barbanera 2000, 43.

${ }^{24}$ Italy was unified in 1861, as a monarchy under the king Vittorio Emanuele, formerly the king of the Piedmont State. The Papal State was conquered and completely annexed in 1870, when Rome became the Capital of the new political entity. 
the educational system. It was evident that antiquities were state property and the government had to take care of them. The Edict of Cardinal Pacca was maintained in force and extended to the rest of the country until a new set of laws was created. The bureaucratic organization underwent many changes before having a stable, capable layout, under the control of the Ministry of Education (Ministero della Pubblica Istruzione). Rome, as the Capital of the new country, had to be remodeled for practical and ideological purposes. Ancient monuments were made 'free,' isolated from later constructions. Antiquities were used as the fundamental symbol of national identity, as an image of grandeur, and finally as a statement against the Church's power. ${ }^{25}$ In 1870, a new excavation was undertaken in the Roman Forum and from the buildings sites scattered throughout the city many archaeological remains came to light. Pietro Rosa (1810-1891) was appointed Superintendent for Excavations of Antiquities in Rome. In 1872, the Archaeological Commission of the city of Rome (Commissione Archeologica Comunale) was created with its own journal. ${ }^{26}$ In the same year the publisher Loescher founded the Rivista di Filologia Classica, the first Italian journal entirely devoted to Latin and Greek studies. ${ }^{27}$ The Academy of Lincei created a new section for humanities in 1874 and published, in 1877, the first issue of Notizie degli Scavi di Antichità, intending to

${ }^{25}$ In 1866 the Italian Government dissolved religious orders and congregations; several churches, buildings, estates and also furniture and objects became state property, including archaeological finds and fine arts. (R.D. July 7, 1866, n. 3036, promulgated under art. 2, 1 c, lett. b of the Law June 28, 1866, n. 2987). In 1873, when also the remains of the territories of the Papal State had been acquired to the new Italian kingdom, the same regulation was applied to the province of Rome (L. June 19, 1873, n. 1402).

26 The Bullettino della Commissione Archeologica Comunale di Roma, where first notices of the excavations in Rome were published. The new Commission was the heir of the Papal State’s Commissione alle Antichità (or di Belle Arti).

${ }^{27}$ Currently under the name Rivista di Filologia e di Istruzione Classica. 
inform scholars about excavations in the whole country. New museums were created as research centers (e.g., the Etruscan Museum in Florence) and competency conflicts arose among these peripheral bodies, lacking a Central Division, as in the case between the Archaeological Commission of the city of Rome and the Superintendency. For the first time, in 1874 , Italy was able to assign an adequate amount of funds specifically to excavations and archaeological sites, many of which had been researched in the last quarter of the century (in Rome, Pompeii, Sicily, Calabria, northern Italy, etc.). In 1875 Giuseppe Fiorelli (1823-1896), professor of Archaeology at the University of Naples since 1861, was appointed Director for Excavations and Museums of Antiquities (Direttore Generale degli Scavi e Musei di Antichità) and some of the peripheral bodies created in the meanwhile were abolished (e.g. the Superintendencies of Rome and Naples). Under the Central Direction, Italy was divided into three districts, ${ }^{28}$ with two special commissions for Sardinia and Sicily. Fiorelli began to collect all the laws from the preexisting states in order to create a compendium, but he had no chance to fulfill the task and at the beginning of the XX century no national law was yet in force. Some of the problems he had to confront had been on the agenda of Italian archaeology for a long time, and some still are: lack of funds, lack of highly specialized personnel, and need for a consistent set of regulations. Giuseppe Fiorelli is probably the most outstanding figure of this period. He began his career under the Borbone ${ }^{29}$ and he is famous in particular for his research at Pompeii. He received a traditional antiquarian education, but he was aware of the need for change. His statements about the discipline are clear and still valuable:

${ }^{28}$ North, administered by Gamurrini, Center administered by Rosa, and South administered by Fiorelli himself. Advisory members were also Brizio and Pigorini.

${ }^{29}$ Since Fiorelli joined in the revolt against the Borbons in 1848 he was fired and he was back on the archaeological scene only in 1860, when the Kingdom of Naples ended. 
documentation of excavations and quick publication of the results, creating the Giornale degli Scavi di Pompei (1861-65); field training for archaeologists, creating the School of Pompeii; importance of excavation context and topographical context, elaborating rules for digging; and the need for combining theory and practice. ${ }^{30}$ His approach focused on the excavation methods ("scavo dell'attenzione" - "careful digging") and on the importance of the archaeological remains as evidence of everyday life in antiquity. There is, in Fiorelli, a perspective different from history of art and archaeology as the ancilla of philology, as it was in Germany. Germany, which had also been unified in the same period and had a high political prestige at the time, ${ }^{31}$ had a profound influence on the development of archaeology as a discipline in Italy. Many Italian archaeologists of this period had studied in Germany. The German Idealistic model won against the minority stream of Positivists, represented in Italy especially by scholars interested in prehistory and in some way by Fiorelli. Three episodes exemplify the situation: the Archaeological School of Pompeii; the change of status of the former International Institute of Archaeological Correspondence in Rome; and Löwy's appointment to the first chair of Archaeology at the University of Rome.

In 1866 Fiorelli wrote a proposal in order to create an Archaeological School in Pompeii, where students would be trained on site. The funding he received was not adequate and the first admission procedure failed, lacking acceptable applicants. In 1868 only three candidates had been admitted. In spite of his efforts, the project turned out to be unsuccessful and Fiorelli was not supported enough because he was following a direction opposite to the

${ }^{30}$ On Fiorelli see in particular Barbanera 1998, 19-34, and infra. The Giornale degli Scavi di Pompei became the model to be followed by Notizie degli Scavi di Antichità.

31 The high self consciousness of Germans at that time and their opinions about Italy can be well summarized in the Metternich’s sentence, see n. 1. 
Altertumswissenschaft. He was not against the study of classical texts, but he knew that the Italian educational system could not count on the solid structure of the German Gymnasien. The German perspective was growing more and more: the Institute of Archaeological Correspondence had become a Prussian Institute in 1871 and international scholars lost their roles. In 1890 the Austrian scholar Emanuel Löwy was appointed as the chair of Classical Archaeology in Rome. ${ }^{32}$ He was a young, innovative scholar, who did not undervalue the importance of field archaeology, but his main interest was the history of art. Such a decision had long-lasting effects on the discipline in Italy, because it drew the route for archaeology as history of art. Paolo Orsi (1859-1935), ${ }^{33}$ who was the candidate not appointed, had a different curriculum and a perspective similar to Fiorelli's. He had studied in Padova, Vienna, and Rome, being also a student of the famous anthropologist Luigi Pigorini. From 1888 Orsi was the Archaeological Inspector in Sicily and he worked extensively there and in Calabria, after not being appointed at the University of Rome. His interests were not restricted to Classical Archaeology, but he extended attention to prehistory, indigenous sites and late antique materials, since a site is rarely affected during only one period of time. Surveying and “careful digging” by levels were the methods to which he was devoted..

Even if the majority of archaeologists were supporting the German model, it is worth noting that most of the outstanding characters of this period were attempting a different path. Besides Fiorelli and Orsi, Rodolfo Lanciani and Giacomo Boni are exponents of alternative interpretation of archaeology, based on field research. They both come from different fields of studies, Engineering and Architecture.

${ }^{32}$ In 1892 he founded the Museum of Plaster Casts at the University of Rome La Sapienza, intended to be the most important tool for teaching archaeology (Museo dei Gessi, now Museo dell’Arte Classica).

${ }^{33}$ On Paolo Orsi see also Arias 1976, 15-30. 
Rodolfo Lanciani (1847 - 1929) is considered the father of modern topographical research. His technical education led him to give importance to measured drawings and cartography. He rapidly became influential in Rome and directed many archaeological projects, including the excavations in the Roman Forum in 1884-5. He taught Ancient Topography at the University of Rome beginning in 1882. He was also a controversial figure, involved in illicit traffic of antiquities, but also a great spreader of knowledge and an international level celebrity, lecturing in the United States. Lanciani is often accused of being passive in front of the sterri (large-scale, inaccurate and imprecise excavations) in Rome, more interested in the big urban picture rather than in a single small site. His topographical research was synthesized in his works, published in the first years of the XX century and still fundamental in Roman archaeology. ${ }^{34}$ He had several government assignments and became a senator of the Kingdom.

From 1898 to 1911 Giacomo Boni (1859 - 1925) excavated the Roman Forum, which had had been almost completely 'unearthed' under the direction of Rosa (1871-1880) and Lanciani (1884-5). As an architect, he had no philological education and he acquired notable success thanks to the accuracy of his methods in excavating. He was able to recognize the Lapis Niger and he turned his attention to early republican Roman levels. Boni represented the first attempt to conduct a stratigraphic excavation and was a pioneer in the use of aerial photography for archaeology, utilizing an aerostatic balloon. Boni theorized his methodology, the rules of archaeological excavations, showing attention to geology, potsherds, and ancient masonry techniques. ${ }^{35}$

${ }^{34}$ Lanciani's Forma Urbis Romae and Storia degli scavi di Roma, as well as other of his works, are still in print; agenda for new edition; cfr. Lanciani 1989.

${ }^{35}$ Boni 1901. 
At the beginning of the $\mathrm{XX}$ century two different ways to interpret archaeology are evident: the Idealistic one, with Löwy and his followers, who were more interested in art history, and the positivist-empiricist model of Boni, who was accused of not having any depth in historic questions. Nevertheless, Boni attempted the first serious effort to use methods developed in the excavation of prehistoric sites and exported them to classical archaeology. The two paths did not necessarily diverge as the next generation of archaeologists acknowledged the importance of both of them and were able to benefit from each. The School of Archaeology of Rome, led by Löwy (classical archaeology) and Pigorini (prehistory), attests that the two trends joined efficiently, affecting scholars who felt no inferiority compared to the German approach. The discipline in Italy was becoming more developed and secure, thanks also to the improvement of the educational system, a more mature bureaucratic organization, and the first important missions abroad. In 1909 the Royal Italian Archaeological School of Athens was founded, the last in order of time among other foreign institutions in Greece. The School was founded after almost 15 years of Italian activities in Greece. In 1884, Federico Halberr, a young Italian epigraphist, discovered the Gortyn inscription in Crete and began excavating and surveying there. The private initiative was supported in 1899 by the Italian Government. The mission in Crete was promoted also by the press, academies, and political interests, but moved on slowly because of lack of funds. The successful excavations in Gortyn, Phaistos, and Prinias, and the new colonialist interest of Italy contributed to the creation of the Italian Archaeological School of Athens, where Luigi Pernier was appointed director. Doubtless, Italian colonialist expansionism supported archaeological activities and the history of Italian archaeological missions abroad intertwined with political and economic interests. The war between Italy and Turkey began in 1911 and Italian archaeologists 
interested in North African Roman sites took advantage of the new political situation. ${ }^{36}$ Italy occupied the Dodecanese islands in 1912, and excavations in Rhodes began, while Crete was annexed to Greece in 1913. Roberto Paribeni, Amedeo Maiuri, Pietro Romanelli, Salvatore Aurigemma, Alessandro Della Seta, and Biagio Pace were the new generation of archaeologists, the first to be trained in archaeological missions abroad, in Greece, Asia Minor, and Libya.

Italian Archaeology was no longer under German influence and the discipline had an autonomous development, thanks also to the contributions of researchers working on prehistory. In 1913 Alessandro Della Seta, who became Director of the School of Athens in 1919, wrote: "An Archaeologist is the digger who recovers buried remains of past civilizations, stone tools, Pompeian paintings or Christian sarcophagi; each 'product' is a conquest for archaeology. An Archaeologist is someone who investigates above the ground [...] the topographer [...]. An Archaeologist is the paleoethnologist, is the art historian, is the epigraphist $[\ldots] .{ }^{, 37}$

In 1907 the General Direction for Antiquities was reorganized and Superintendencies were created as peripheral bodies. Finally, in 1909 the first national law concerning cultural heritage was issued, with the acknowledgment of archaeological remains as state property. ${ }^{38}$ By then, archaeology was increasingly used as a means for cultural identity. In 1913 the

${ }^{36}$ After the annexation of Libia territory, Tripolitanian Antiquities were administered by the Italian General Direction for Antiquities and Fine Arts. In 1913 a new Superintendecy was created at Bengasi, directed by Salvatore Aurigemma. Excavations took place at Cyrene and Lepcis Magna.

${ }^{37}$ Barbanera 1998, 115 (translation by M. De Simone); Della Seta, 1913.

38 Legge 20 giugno 1909, n. 364, which establishes and sets standards for the inalienability of Antiquities and Fine Arts (as integrated by the following laws and regulations: L. June 23, 1912, n. 688; R,D. January 30, 1913, n. 363 R.D.L. November 24, 1927, n. 2461 as converted into L. May 31, 1928, n. 1240). 
Superintendencies became responsible for disseminating the excavation data and making them accessible to scholars and the broader audience, initially through Notizie degli Scavi $e$ Scoperte di Antichità, published by the Accademia dei Lincei. ${ }^{39}$ In 1911, during the celebration for the fiftieth anniversary of the founding the Kingdom of Italy, an archaeological exhibition was held in Rome at the Baths of Diocletian (Terme di Diocleziano), where the National Roman Museum had been founded in 1889. Lanciani was the curator of the exhibition. Such a rhetorical use of archaeology and 'Romanity' would be a characteristic of the Fascist era.

\section{The Fascist Era. Archaeology at the Service of Power}

In 1922 Mussolini came to power in Italy, establishing the Fascist era, even if the pathetic phantom of the kingdom was left in place. The totalitarian structure forced intellectuals to align themselves. Especially in the last period of Mussolini's power, some archaeologists, because they were antifascist or Jewish, were removed from their positions. ${ }^{40}$ Other archaeologists exploited the situation for their own gain. ${ }^{41}$ At the beginning, however, the academic world did not suffer traumatic changes. The discipline of archaeology was developing in specific directions. Idealism and the influence of Benedetto Croce finally overwhelmed the Positivistic approach. At the same time, the School of Vienna also affected Italian archaeology. Roman, Etruscan, and Italic Arts were 'rediscovered' as worthy and to be analyzed not with out-of-date parameters founded on Greek art. Italian missions abroad

${ }^{39}$ Art. 83 of R,D. January 30, 1913, n. 363.

${ }^{40}$ In 1938 Racial Laws were issued in Italy. See, e.g., the case of Alessandro Della Seta, Director of the Italian School of Archaeology in Athens since 1919, removed in 1939.

${ }^{41}$ The affair of Jacopi and Segre is exemplar, Barbanera 1998, 150-1. On archaeology and Fascism see also Manacorda, 1982. 
continued in the Dodecanese islands, Turkey, Albania, Libya, Greece, and Egypt. The aggressive strategy of the Italian government supported archaeological activities. In 1923 the National Council for Research was created (Consiglio Nazionale delle Ricerche). ${ }^{42}$ In 1922 the Italian Institute of Archaeology and Art History, created in 1918 on the initiative of Corrado Ricci (1858-1934) in Rome, was established by law. ${ }^{43}$ The Institute was meant to provide bibliographical support for scholars. In 1922 the Library of the Institute (Biblioteca dell'Istituto di Archeologia e Storia dell'Arte) was officially opened and in 1929 the journal Rivista dell'Istituto Nazionale di Archeologia e Storia dell'Arte was created. Another important journal dating back to this period is Studi Etruschi, which testifies to the new attention toward Etruscan art and archaeology. A fervent scholar interested in Etruscology was Giulio Quirino Giglioli (1886 - 1956), who was probably one of the most important figures of this period. Strongly associated with Fascism, he had studied under Löwy and Lanciani, and was especially influenced by the latter. He held the chair of archaeology in Rome ${ }^{44}$ and excavated the mausoleum of Augustus, following the new imprint of Fascist urbanism by isolating monuments as symbols of power. He was also the curator of the Augustan exhibit (Mostra Augustea della Romanità) in 1937, celebrating the bimillennium of the birth of the first Roman Emperor. The regime, devoted to the cult of Rome, had already created the

${ }^{42}$ At the present in the CNR are active four Institutes related to archaeology: Institute for technologies applied to cultural heritage; Institute for the study on the italic and ancient Mediterranean civilizations; Institute of archeological heritage - monuments and sites; and Institute for the Conservation and Promotion of Cultural Heritage.

${ }^{43}$ L. January 15, 1922, n. 10. In 2003 the Institute has been privatized, while maintaining a very close bond with MiBAC.

${ }^{44}$ His favorite student was Massimo Pallottino, worldwide considered one the most important name in Etruscan studies. 
Museum of the Roman Empire in 1927; a new location was meant to be built on the occasion of the Universal Exposition of 1942. World War II interrupted the project, which was eventually completed long after the war. In 1955 the Museum of Roman Civilization was inaugurated in a Fascist-style building in Rome. ${ }^{45}$ Since ancient traditions were a means of legitimizing power and strengthening patriotism, the Fascist regime intended also to protect cultural heritage. In 1939 the most important law on artistic, historic, and archaeological objects was issued and was in effect until $1999 .{ }^{46}$

Large scale excavations of this period were carried out, for the most part, without any concern for levels or stratigraphy. Guido Calza (1879-1946), who worked at Ostia from 1912 and for the rest of his life, unearthed most of the city and completely deleted late antique phases. $^{47}$ Amedeo Maiuri (1886 - 1963) had been digging in Pompeii since 1927 with a similar method. His attention was devoted to the monument as a whole, rather than to stratigraphic layers and findings. In an urban context like Rome such an assumption was devastating. ${ }^{48}$ Nevertheless, other archaeologists, such as Nino Lamboglia, were following different paths.

${ }^{45}$ For urbanism and archaeological excavations during the two decades of Fascism, see: Insolera 1971, Cederna 1979, and Manacorda and Tamassia 1985.

${ }^{46}$ L. June, $1^{\text {st }}, 1939$, n. 1089.

${ }^{47}$ The first volume of the final publication of the excavations, however, is still exemplar and a valid tool for research; see Calza et al. 1954. The series Scavi di Ostia contains 14 volumes, the most recent published in 2000.

${ }^{48}$ The excavation of the Imperial Fora in Rome and the opening of Via dell'Impero (now Via dei Fori Imperiali), connecting Piazza Venezia and the Colosseum, involved the destruction of medieval and renaissance neighborhoods. 


\section{The Second Half of the XX Century}

With the collapse of Fascism and the end of World War II many situations changed, starting with the birth of Italy as a Republic. Such changes had no effect on the influential people in the field of archaeology; for the most part, archaeologists who held chairs or other institutional appointments were easily able to maintain them. If a renewed impulse arrived, it was simply due to a natural generational change. Many journals flourished, some absolutely authoritative even now, such as Fasti Archeologici (1946), ${ }^{49}$ La Parola del Passato (1946), and Archeologia Classica (1949). It was therefore a bipolar era, with a mixture of out-of-date approaches and attempts at innovative methods. The most influential figures after World War II may be recognized in Nino Lamboglia and Ranuccio Bianchi Bandinelli, as representatives of two different interpretations of archaeology. They were both pioneering efforts, with Lamboglia in excavation methodology and Bianchi Bandinelli in art history.

In the years immediately after World War II, Nino Lamboglia (1912 - 1977) was the only representative heir of the 'positivistic' approach. Influenced by prehistoric excavation methods, he was devoted to stratigraphic excavations and to the relationships among layers, materials, and structures. His work at the ancient town of Albintimilium (in Liguria) is exemplary of his method. ${ }^{50}$ Lamboglia is a sort of peripheral scholar, but the Institute of Ligurian Studies, which he founded, is still very active and up-to-date. At the present, the Institute hosts an interdisciplinary school of archeological methods.

49 "Fasti Archeologici” is now also a new project on line, held by AIAC (Associazione Internazionale di Archeologia Classica, International Association of Classical Archaeology).

See: http://www.fastionline.org/

${ }^{50}$ Lamboglia 1950. 
Ranuccio Bianchi Bandinelli (1900-1975) was General Director of Antiquities and Fine Arts in 1945-1947, but he came out frustrated by the experience. He was disgusted by the system of management of the cultural heritage and by the old fashioned style of academic and political disputes. ${ }^{51}$ Being politically active and a Marxist, he was also partially isolated in the academic world. Nevertheless, for his undeniable prestige and capacities, he held the chair of Classical Archaeology in Rome. Most major contemporary scholars were his students (Andrea Carandini, Mario Torelli, Filippo Coarelli, and Paul Zanker). His main interest, even if developing in form, remained archaeology as art history. In 1958 the first volume of the Enciclopedia dell'Arte Antica, Classica ed Orientale, one of his biggest projects, was published. Requested by his students, in 1967 Bianchi Bandinelli founded Dialoghi di Archeologia, a journal intended to offer a chance for dialogue among archaeologists. The decision, supported by his students, was undertaken after the failure of the Society of Italian Archaeologists, ideated by Massimo Pallottino. ${ }^{52}$

Andrea Carandini, born in 1937, is probably the archaeologist who first had the chance and the skill to combine Lamboglia's and Bianchi Bandinelli’s approaches. At Carthage he had the opportunity to experiment with the new stratigraphic methods used by British archaeologists. His attention to understanding material culture and the excavations at Settefinestre, $^{53}$ in the ager Cosanus (southern Tuscany), have been models for all contemporary archaeologists.

\footnotetext{
${ }^{51}$ Bianchi Bandinelli 1974.
}

${ }^{52}$ Barbanera 1998, 162-5. Dialoghi di Archeologia ended in 1992, but it is continued by a new journal, Eutopia.

\footnotetext{
${ }^{53}$ Carandini 1985.
} 
In the past twenty years, Landscape Archaeology ${ }^{54}$ has become very popular in Italy and it results in one of the best ways to approach archaeological research in order to understand and reconstruct the history of peoples within contexts. As a sub-discipline of Archaeology and given its multi-faceted interpretation, it is also the one that better reacts to changes of fashion brought by the latest archaeological theories and approaches. ${ }^{55}$ In the early XX century, Lanciani and Ashby (Director of the British School at Rome) had established the tradition of passeggiate (walks) in the Roman campagna. The richness of the archaeological evidence to be recorded and catalogued on a systematic basis had not escaped Italian scholars, still ‘monument-oriented', such Gamurrini, Cozza, Pasqui, and Mengarelli, who had already envisioned the necessity of creating an Archaeological map of the whole Italy in the late XIX century (their volume was published almost a century later). ${ }^{56}$ This approach would be the starting point for the Topographic method that characterizes the 'school' of the Roman University, where a 'cattedra' (chair) of Topography was established, first held by Lanciani, followed by Lugli and later by Castagnoli. The Forma Italia project is the product of such an approach, which aimed to record and document on a geographical base all the archaeological evidence (based on the IGM maps). In the 1950s the real founding father of the ante-litteram Landscape Archaeology of British tradition in Italy was John Ward-Perkins. As Director of the British School at Rome, he started the South Etruria Project (unfortunately he only published one volume, on Veii), which is considered the first landscape project in Italy. Timothy Potter, who contributed to the project, was among the first to utilize the 'new tools' of quantitative

${ }^{54}$ See for instance: Archeologia del Paesaggio 1992; Cambi and Terrenato 1994, 25-43; Attema et alii 2002; Campana and Piro 2009.

${ }^{55}$ Terrenato 1996, 217.

${ }^{56}$ Gamurrini et alii 1972. 
archaeology (for instance the weighted Thyssen Polygons) in interpreting the data- ${ }^{57}$ The South Etruria Project was then followed by another outstanding research initiative, on the Biferno Valley. ${ }^{58}$ This was carried out by Graeme Barker (as Director of the British School at Rome), who improved the investigation by integrating all kinds of data (paleoecology, geology, etc.). The additional data were intended to better reconstruct the landscape, both physically and culturally. Landscape archaeology is successful in interpreting and reconstructing the history and culture of a region only if it acquires real archaeological data from a survey. Such projects have increased and indeed flourished in recent years, for practical, theoretical and technological reasons: the growing political interest in the landscape, which needs to be known and preserved for society’s progress (zoning projects, rescue archaeology); the Academia's focus on the territory for understanding the bigger picture, i.e. the 'palimpsest' we intend to reconstruct; the development of technology borrowed for archaeological practice from other disciplines, such as remote sensing analysis, geomagnetometry and resistivity, as well as pollen samples studies and geological soundings, GIS, 3D modeling and computer aided spatial analysis. These three elements are now well represented in the stakeholders' agenda in terms of protection of Italian Cultural Heritage, and this is how Tutela (Protection and Long-term Preservation), Ricerca (Research) and Valorizzazione (Communication and Public access) probably work best together.

\section{Management of Archaeological Heritage}

Article 9 of the Italian Constitutional Chart (1947), among the Fundamental Principles, reads:

\footnotetext{
${ }^{57}$ Potter 1979.

${ }^{58}$ Barker 1995.
} 
"The Republic shall promote the development of culture and of scientific and technical research.

It shall safeguard the natural landscape and the historical and artistic heritage of the Nation." 59

In 1974, the Ministry of Cultural Heritage (Ministero per i Beni Culturali e Ambientali) was created by the initiative of Giovanni Spadolini, who became its first Minister. The whole system underwent a comprehensive reorganization, with institutes and other bodies moved from the Ministry of Public Education to the new department. The Ministero per i Beni Culturali e Ambientali had competency on Tutela (Protection) and Valorizzazione (Communication and Public access). Its Institutes also had commitments for Ricerca (Research), which was, however, specifically intended to pertain to Universities and Research Centers. ${ }^{60}$ In the years $1998-2013$ a new set of regulations was created and the Ministry was also affected by several important changes, including its name: Ministero dei beni e delle attività culturali e del turismo (MiBAC). ${ }^{61}$ In 1999, a collection of laws under the name of ‘Testo Unico’ replaced the old L.1089/1939 and only few years later, in 2004, it was in turn replaced by the Codice dei Beni Culturali e del Paesaggio. ${ }^{62}$ In the meantime, the Parliament had also modified the Italian Constitutional Chart by redefining the attributions and

${ }^{59}$ English version available at: http://en.camera.it/4?scheda_informazioni=23.

${ }^{60}$ See Law December 14, 1974, n.657, art. 2, and D.P.R. December $3^{\text {rd }}, 1975$, n. 805. Universities and other scientific research centers were under the administration of the Ministry of Scientific Research, which does not exist anymore. At the present, they are under the administration of the Ministry of Education, Research, and University. Universities have guaranteed to be autonomous.

61 The latest changes were issued by D.P.R. July $2^{\text {nd }}, 2009$, no.91 and by Law June $24^{\text {th }}, 2013$, no.71.

${ }^{62}$ L. January 22, 2004, no. 42, as integrated by L. March 26, 2008, no. 62. 
relationships between State and Regions. ${ }^{63}$ The results of this reform, for the object of the present study, can be summarized as follows:

- Long-term protection and preservation (i.e. tutela) are priority values and state attributions, while both State and Regions are in charge of communication and public access (i.e. valorizzazione). In the name of sincere cooperation between the institutions, the State (with the MiBAC and its peripheral bodies) and the Regions work together, by acknowledging a development already in progress in recent years (since the creation of the Regioni in 1970) and by harmonizing laws and regulations on the subject;

- Increase of responsibilities of individuals and participation of private holdings (through outsourcing and sponsorships), aimed at achieving more efficient use of human and economic resources.

This complex system of regulation and control is necessary in a country with such an impact of the historical, artistic and landscape heritage; it is the result of a long tradition and of the peculiarities of Italy, not least the ever-present risk of clandestine excavations and illicit trade.

Clandestine excavations and illicit trafficking of archaeological material are still a plague on the Italian scene. ${ }^{64}$ Although Italy has always been at the forefront on this issue,

${ }^{63}$ Constitutional Law October 18, 2001, no.3.

${ }^{64}$ The most recent incident pertains to 23 Etruscan urns and about 3,000 other archaeological findings recovered near Perugia, as in the news of June $27^{\text {th }}, 2013$ (http://www.adnkronos.com/IGN/Regioni/Umbria/Perugia-i-Carabinieri-recuperano-23-urne-etrusche-e-3-milareperti-archeologici_32340100005.html and http://video.corriere.it/23-urne-etrusche-ritrovamentoperugia/3182dcaa-df38-11e2-b08d-5f4c42716abd). 
both from the regulatory point of view and from the organizational one, archaeological heritage is constantly being looted. ${ }^{65}$ Worthy of mention is that a Special Unit of the Carabinieri (Italian Military Police) cooperates with the Ministry in order to counteract illicit trade and illegal excavations. The Art Squad (Comando Carabinieri Tutela Patrimonio Culturale) began its activity in 1969, a few years earlier than UNESCO approved the “Convention Concerning the Protection of the World Cultural and Natural Heritage” (Paris, 1972). Italy was the first country that had a special Police Department for protecting cultural heritage, currently coordinating other groups of police, such as the Guardia di Finanza Gruppo Tutela Patrimonio Archeologico. In the early XXI century, more active international agreements, as well as few 'scandals' and trials, ${ }^{66}$ led to a major repatriation of artifacts looted in the last 30 years of the XX century (after the approval of UNESCO Conventions of Paris, in 1970 and 1972): Euphronios' krater, the Aphrodite and the silver hoard from Morgantina, the Vibia Sabina statue, are only few examples of the many archaeological pieces recently returned to Italy from the most important international museums. As an exchange, Italy is now supporting a policy of international short- and long-term loans of archaeological masterpieces for major exhibitions in international museums. The general audience is more and more conscious of the problems caused by illicit trade, thanks to a series of exhibitions held in

${ }^{65}$ In 2001, MiBAC and the Carabinieri Art Squad organized a conference devoted to illicit trafficking. The proceedings volume, edited in the Supplementum no 38 of Bollettino di Numismatica, offer a thorough overview of the question at the beginning of XXI century: cfr. Traffico 2002.

${ }^{66}$ Watson and Todeschini 2006; Nostoi 2007: 35 and ff. 
recent years, which served to return all the "stolen” masterpieces to the public interest. ${ }^{67}$ The increased public awareness ensures better protection of antiquities and a renewed impulse to fight illicit trafficking.

Paolo Giorgio Ferri, an Italian magistrate, expert on juridical problems related to cultural heritage and consultant for MiBAC, highlights how “this 'new Italian deal' takes advantage of the recent trend of museums whose educational mission seems addressed not to acquire assets in property, but to the organization of special exhibitions and related educational activities.”68 Once the ‘collecting mania’ phase has been overcome, museums can fulfill their particular intentions as stated in the International Council of Museums' mission definition. $^{69}$

This trend, however, which may seem to be optimal, raises at least two risks: the 'mostrificio, ${ }^{70}$ and excessive 'monetization' of cultural heritage. The focus should not, in fact, be given only to well-known breath-taking masterpieces, but to reconstruct their context and

${ }^{67}$ Nostoi, Capolavori ritrovati was the exhibition held at the Presidential Palace in Rome (Quirinale) in 2007-2008); many others followed as La felicità di un ritorno, Rome 2008; I predatori dell'arte, Rome 2012; Capolavori dell'Archeologia, Rome 2013; see the relative exhibitions catalogues.

${ }^{68}$ Ferri 2012.

69 “A museum is a non-profit, permanent institution in the service of society and its development, open to the public, which acquires, conserves, researches, communicates and exhibits the tangible and intangible heritage of humanity and its environment for the purposes of education, study and enjoyment.” ICOM Statutes, Vienna 2007.

70 The term 'mostrificio' is impossible to translate, since it plays on the words mostra/mostro (exhibition/monster) and -ficio (factory); it is to say that this new trend may produce useless and countless bad exhibitions just for profit and not having in mind serious research and education. 
deliver our past through archaeology. A recent bill (art. 14), ${ }^{71}$ which is to be submitted to the Chambers for deliberation, intends avoiding, at least partially, these risks. It aims, in fact, to safeguard the legitimate interests of foreign museums to exhibit Italian cultural heritage for long terms, focusing not on the usual 'pieces', but on other ones, less known and no less relevant. In addition, it plans to draw a profit from these extended loans, in order to sustain conservation and protection of cultural goods: "Temporary exit from Italy of cultural goods from museums' repository (not on display), on request by foreign museums, allows a fee to be requested for the economic exploitation of such property for a period not to exceed ten years (renewable once).” 72

Public opinion is already divided in this respect, because of the peculiar, and somehow safe, Italian taboo concerning the economic exploitation of cultural heritage.

The 'mostrificio' risk is well-known and debated in Italy, questioned because it tends to respond to market logic that does not always match with the seriousness and consistency of exhibition projects. Major events and the 'exhibition-mania' are always supported by massive advertising projects and drain financial resources. As a result, the ordinary gets less and less funding with related problems in terms of protection and conservation. In addition, these kinds of blockbuster exhibitions do not help to educate the audience to a more conscious use of cultural activities, if not superficially; they often overshadow excellent projects that do not have adequate funds (or do not want to waste them) on marketing. ${ }^{73}$ In 2002, Salvatore Settis

${ }^{71}$ Document available at: http://www.lagazzettadeglientilocali.it/quotidiano/2013/200613/decreto_semplificazioni_19_giugno.pdf, 72 http://www.governo.it/Governo/ConsiglioMinistri/dettaglio.asp?d=71736, June 19, 2013; my translation.

${ }^{73}$ Guerzoni 2012: 3-4. 
expressed sharp criticism in this regard: “The concept of the exhibition as a 'catch-tourist tool' is culturally old-fashioned and corresponds to a short-sighted economic point of view. It may lead to sudden increase of interest and crowds of visitors and then to desert and silence. It may promote, or at least legitimize, the lack of culture and the desertion of the permanent collections of museums for the benefit of ephemeral events." ${ }^{74}$ Such a pessimistic view is justified by the chronic reduction of public funding for managing cultural heritage and by the idea that similar events do not necessarily increase the audience's cultural consciousness. It must be said, on the other hand, that most of the museums' displays are often out-of-date, while temporary exhibitions, with their new settings, are more effective in terms of communication, by exploiting modern media, communication strategies, and information technologies. ${ }^{75}$ Therefore, financial resources should be used to reinforce display-settings of permanent collections and increase communication, instead of getting lost in a myriad of transient and expensive events, not always scientifically adequate for the issues addressed. Moreover, too often temporary exhibitions aim to highlight masterpieces, as a means to appeal to the public, instead of focusing on the context and the set of data which go with that unique work of art. The result among the audience is the exact opposite of what archaeology is about.

From a contemporary archaeologist's point of view, the attention to a single object of art is very risky and is at the base of the same mental process that leads public opinion to be outraged by recent collapses at Pompeii ${ }^{76}$ and by the Colosseum shut down by striking

\footnotetext{
${ }^{74}$ Settis 2002: 94, my translation.

${ }^{75}$ Saioni 2012:27-28.

${ }^{76}$ See www.ilmessaggero.it, June $30^{\text {th }}$, 2013, "Pompei, dossier degli ambasciatori: scavi a rischio, alta
} umidità.” Pompeii and Herculaneum being listed as World Heritage Sites since 1997, UNESCO is currently urging Italian Government to address the problems of the "long-term sustainability of future management and 
workers. ${ }^{77}$ It is the same public opinion that blames archaeologists when they try to protect the landscape against illegal building; that tolerates cutting of funds to public education; that believes private holdings may become a panacea for the struggling Italian management system of Cultural Heritage.

In order to analyze and understand the difficulties and issues related to cultural heritage, one cannot ignore the concept that these cultural goods are public property and therefore they should continue to be administrated by public institutions. Common interest is what should guarantee the same attention to both famous sites and research excavations, to renowned masterpieces and ceramic fragments, by protecting archaeological heritage that is not only Italian, but the common good of the whole world.

The joint participation of private holdings can be very positive; nevertheless, in the Italian tradition the private interest does not coincide with the public interest (as often is the case in different cultures). This is one of the reasons why the private sector cannot be seen as a

conservation of the site” (UNESCO Report, 2013: 32). The World Heritage Committee will "monitor closely the state of conservation of the property, by requesting annual progress reports. If for any reason, the on-going initiatives [i.e. the Great Pompeii Project, funded by European Union, see infra] fail to deliver substantial progress in the next two years, the World Heritage Centre and the Advisory Bodies recommend to the Committee to consider the possible inscription on the List of World Heritage in Danger in 2015.” (UNESCO WHC, 2013: 144-145).

${ }^{77}$ Taking the opportunity offered on June $20^{\text {th }}$ and 23th 2013, when the Colosseum has been shut to the public for a strike, the journalist Simonetta Fiori interviews Massimo Bray, appointed in 2013 as Minister at MiBAC. The journalist addresses several questions that are in the current agenda for the management of Cultural Heritage: “Sciopero, Colosseo chiuso. Bray: voglio più risorse” June $24^{\text {th }}$, 2013, on repubblica.it, available at: http://www.repubblica.it/cronaca/2013/06/24/news/sciopero_colosseo_chiuso_bray_voglio_pi_risorse-

$\underline{61750880 / .}$ 
solution in cultural heritage management. By counting too much on private funding, cultural heritage may become more and more monetized and different stakeholders may not agree on what is the common interest. While the Colosseum and Pompeii will always be in the spotlight, other sites and activities, less appealing but necessary to the system, may not be funded by private sponsors, especially when there is a conflict of interests.

In the last ten years public funding for MiBAC has been dramatically cut in half. The MiBAC Annual Report for $2012^{78}$, besides many interesting quantitative data, shows how economic resources available are decreasing every year and are absolutely inadequate, especially when compared with percentages of the State Budget and GNP (fig. 3, currency in Euros). Because of its peculiarity, Italy cannot renounce public management of cultural heritage and in recent years has been pursuing several strategies to exploit direct and indirect private support and to counteract a chronic lack of funds:

- Lotto. The Italian government has been using a percentage of lottery income for funding cultural heritage restoration and protection activities. ${ }^{79}$ In 2007-2009 more than 57 million euros from such a source have been utilized for archaeological sites

\footnotetext{
${ }^{78}$ Minicifre 2013.

${ }^{79}$ L. December 23, 1996, no.662, art. 3, c.83.
} 
and museums. ${ }^{80}$ Unfortunately this kind of financing has also been dramatically reduced (2013 attests a decrease of $81 \%$ compared to year 2004). ${ }^{81}$

- Tax Break. Since 1982, Italy has recognized a special tax concession in favor of cultural heritage and activities, both for owners of cultural heritage, which must ensure conservation, and for those who make donations for cultural purposes; contributions can be deduced on donor's tax return statement. ${ }^{82}$

- Tax Donation (cinque per mille). A recent strategy for acquiring funding has been tried in the past fiscal year (2012): the taxpayer may choose to donate a percentage (5\%) of the tax on personal income withholding (Italian IRPEF), to the protection, promotion and enhancement of cultural and natural heritage. ${ }^{83}$

- Profit from extended loans of cultural heritage to foreign institutions. ${ }^{84}$

- Sponsorship. Article 120 of the Law on Cultural Heritage ${ }^{85}$ indicates the way sponsorship can reduce public spending through private contributions, in order to

${ }^{80}$ Information available on the MiBAC website:

http://www.beniculturali.it/mibac/opencms/MiBAC/sito-

MiBAC/MenuPrincipale/GrandiRestauri/InterventiDiRestauroConIFondiDelGiocoDelLotto/ Recently also this type of income has been drastically reduced (http://www.lagazzettadeglientilocali.it/pf/testo-news/7357/I-beniculturali-perdono-al-Lotto).

81 These data were presented to the Parliament by the Minister Massimo Bray on May 23, 2013. Cfr. Bray 2013.

${ }^{82}$ Solfaroli Camillocci, 2013.

${ }^{83}$ L. July 15, 2011, no. 111, art. 23, c. 46; http://www.beniculturali.it/mibac/export/MiBAC/sitoMiBAC/Contenuti/MibacUnif/Comunicati/visualizza_asset.html_260308829.html;

${ }^{84}$ Cfr. supra and notes 70 and 71. 
implement actions in the public interest. The concept is perfectly in line with the provisions of the Public Procurement Law, ${ }^{86}$ article 26, to guarantee the protection of the goods and the absence of conflict of interests. ${ }^{87}$ An overall planning for exploiting sponsorships is still lacking, but some good practices have been already enacted, such as the creation, in 2011, of the first provincial agency that aims to bring together sponsors and projects to be sponsored. ${ }^{88}$ Recently MiBAC issued a set of Guidelines for cultural heritage sponsorship. ${ }^{89}$

- Fundraising. The new bill proposed by the Government on June 19th, 2013 aims to simplify fundraising activities devoted to cultural heritage (art. 15). Delegated officials of MiBAC will be able to acquire and re-use donations, for specific action of protection of cultural heritage, simplifying the process of payment to the state and subsequent reallocation of funds. ${ }^{90}$

${ }^{85}$ D. Lgs. January 22th, 2004, no. 42, and further modifications and integrations, Codice dei beni culturali e del paesaggio.

${ }^{86}$ D. Lgs. April 12th, 2006, no 163, Codice dei contratti pubblici relativi a lavori, servizi e forniture.

${ }^{87}$ Falzea 2012: 102-104, 120.

88 This agency operates within the Chamber of Commerce of Monza-Brianza: http://www.mb.camcom.it/show.jsp?page $=752867$

89 D.M. December 19th, 2012: Approvazione delle norme tecniche e linee guida in materia di sponsorizzazioni di beni culturali e di fattispecie analoghe o collegate, "Gazzetta Ufficiale” no. 60, March 12th, 2013; document available at:

http://www.beniculturali.it/mibac/multimedia/MiBAC/documents/1362735663805_CdCSponsorizzazion i.pdf.

${ }^{90}$ http://www.governo.it/Governo/ConsiglioMinistri/dettaglio.asp?d=71736, June 19, 2013; text at:: http://www.lagazzettadeglientilocali.it/quotidiano/2013/200613/decreto_semplificazioni_19_giugno.pdf. 
In addition, service concessions, outsourcing and in-house companies are useful strategies proposed to optimize human and economic resources within the cultural heritage system. ${ }^{91}$

Recently appointed Minister at MiBAC, Massimo Bray aims at guiding the choices towards a close collaboration between the public system and private funding. ${ }^{92}$ At a hearing of the Culture Commissions of the Parliament, on May 23, 2013, the Minister outlined his program and the current difficult situation of MiBAC, relating to human and financial resources.

In the past decades the public has been more and more sensitive about cultural and environmental heritage, thanks to the dedication and efforts of people such Ranuccio Bianchi Bandinelli and Antonio Cederna, ${ }^{93}$ and currently Salvatore Settis. ${ }^{94}$ The actual trend carried on

${ }^{91}$ Io sono cultura 2013: 159-166.

92 Bray 2013: 5-6.

93 Antonio Cederna (1931 - 1996) began his career as an archaeologist and then spent most of his life as a journalist, engaged in fighting abuse and bad management of cultural heritage. He was one of the promoters of the popular association Italia Nostra.

${ }^{94}$ Salvatore Settis $(1941$ - ) is a contemporary Italian archaeologist who has been Director of the Getty Research Institute for the History of Art and the Humanities at Los Angeles, from 1994 to 1999, and has been the Director of the prestigious School of Pisa (Scuola Normale Superiore di Pisa), from 1999 until 2010, where he was also professor of History of art and classical archaeology. In 2002 he wrote a very popular book against the new trend supported by the actual government of Italy on the matter of cultural heritage management (Settis 2002). He was the chairman of the High Council for Cultural Heritage (Consiglio Superiore dei Beni Culturali) from 2007 to 2009, when he resigned because of contrasts with the former Minister Sandro Bondi and because of his criticism on the management of cultural heritage and cut of funding. In February and March 2013, being not only a distinguished scholar but also a very influential intellectual in society and in politics, he has been considered both by broad audience and by scholars as the most appropriate candidate for the Ministry of Cultural Heritage, for which, instead, has been eventually appointed Massimo Bray. 
by the recent governments of Italy moves towards a more consistent participation of private entities in the management and exploitation of cultural heritage. From a certain point of view this is a mandatory choice, since funding is never enough to sustain the complex and, for many years, inefficient organization. Private holdings are very interested in the exploitation of such riches, which has been called the ‘black gold’ (i.e. “oil”) of Italy.

Tourism, monuments, and sites can take some advantage by private companies’ efficiency, but the risk of a classification of monuments and sites, based on their 'economic productivity' is undeniable. Sometimes the cooperation among public and private gives good results, but most Italians are persuaded that it can also become a dangerous threat, a conflict of interest that dates back to Gaius Verres and his robbery of works of art in Sicily. ${ }^{95}$ Fortunately, the audience is interested and kept aware by press coverage, associations and intellectuals. The growing curiosity about culture and cultural heritage is also well demonstrated by flourishing popular magazines, TV programs, websites, and associations of volunteers.

\section{Public Archaeology in Italy: Between Emergency and Prevention}

Engaging a conscious audience is one of the aims of 'Public Archaeology'. The public should not be seen as passive consumer but as a significant element for actions of prevention and decision-making related to the public sphere of archaeology; ${ }^{96}$ this aim is achieved by a rational and conscious debate between archaeologists and non-archaeologists, through a formative process of cultural heritage education. Communication's effectiveness and accuracy

${ }^{95}$ See Tomaso Montanari’s column Beni Culturali sempre più privati, “Il Fatto Quotidiano,” July 6th, 2013, available at: http://www.ilfattoquotidiano.it/2013/07/06/beni-culturali-sempre-piu-privati-sfilate-agli-uffizidella-valle-punta-al-colosseo/648221/.

${ }^{96}$ Matsuda 2004, 71-72. 
become absolutely important in order to avoid the risks of "alternative archaeologies" sometimes offered by popular magazines and TV shows. ${ }^{97}$ Archaeologists need to be involved directly in this process: “today a real 'educational archaeology' is emerging, i.e. an archaeological activity, not delegated to other mediators, but personally conducted by archaeologists with educational, social and cultural objectives and aims."98

Therefore, the common interest is not any longer left to the "public" authority; inclusiveness and active participation of the public (the people) become fundamental to the protection of heritage, in terms of increasing the overall social growth, of which public archaeology turns out to be an instrument. According to Vannini's definition, in Italy Public Archaeology is "an interdisciplinary field that studies and promotes a strategic relationship between research institutions and a broad range of public and private actors of civil society [...]; in other words, its aim is to combine research with its applications, designed to contribute to the achievement of socio-cultural and even economic shared goals; in collaboration with relevant institutions (both central and local), it contributes to the increase in value of the archaeological heritage in favor of the community residents and the territorial productive sectors." ${ }^{99}$ Museums play an important role for cultural and socio-economic regeneration; ${ }^{100}$ they constitute a point of contact and dialogue between the community of specialists and the non-specialist public, becoming an instrument for crafting the "public sphere” of archeology. Therefore archaeological heritage will be perceived not as a risk (and hopefully it will not be at risk!), but a resource.

\footnotetext{
${ }^{97}$ Bonacchi 2009, 339.

${ }^{98}$ Brunelli 2013, 12.

${ }^{99}$ Vannini 2011, 20.

${ }^{100}$ Bonacchi 2009, 342.
} 
In spite of good practices, Italian archaeological heritage very often must cope with emergencies. Unfortunately the Italian peninsula, including Sicily, is a zone of high seismic risk, because of the convergence of African and Eurasian plates. In addition to the human tragedy, the frequent earthquakes seriously endanger cultural heritage. It suffices to cite two recent examples: the collapse of the vault and destruction of frescoes by Giotto in 1997 in the Basilica of San Francesco, Assisi; the complete devastation of the town of L'Aquila in 2009. In 2007 MiBAC issued the Guidelines for the evaluation and reduction of seismic risk of the cultural heritage; the guidelines aim to "identify a path of knowledge, assessing the level of safety against seismic actions and planning future projects [...]; the intent is to formulate, as objectively as possible, the final judgment on safety and conservation, as guaranteed by seismic improvement actions." ${ }^{101}$ In order to implement preventive measures, a thorough knowledge is a priority.

However, in the past situations defined as emergencies have been abused for the purpose of implementing "extraordinary governance" in the sector of cultural heritage, derogatory measures and extra-legal situations. This is essentially what happened at Pompeii (2008) and Rome (2009): with a sort of coup-d'état in the sphere of protection of cultural heritage, the government declared a state of emergency relating to archaeological sites and issued urgent measures of civil defense (Protezione Civile), appointing commissioners who were given extraordinary powers. Here we have to do with a system that is self-referential and centralized, which goes beyond jurisdiction both in terms of scope and territory, and which acts in contravention of standards. These states of emergency resulted in scandals and judicial investigations — but not in solutions of the "emergency situations." There certainly ought to be

${ }^{101}$ Introduction to "Linee Guida per la valutazione e la riduzione del rischio sismico del patrimonio culturale,” Direttiva del Presidente del Consiglio dei Ministri, 12 October 2007. 
a return to normal management since cultural heritage, taken as a whole, cannot be considered an emergency or a threat. ${ }^{102}$

But the true emergency today in the management of the archaeological site of Pompeii is a reality that must be addressed, and so between 2011 and 2012 the "Major Project Pompeii” was born. Through Decree n. 34/2011 (art. 2), the Italian government sought to strengthen the effectiveness of actions and interventions of protection in the archaeological park of Pompeii by working out an extraordinary emergency program of initiatives of conservation, prevention, maintenance, and restoration. EU and national Italian funds were obtained in the amount of ca. E. 105 million. The "Major Project Pompeii” involves MiBAC, the Ministry of Cohesion, the Interior Ministry, and the Ministry of Education, Universities, and Research. The President of the Authority of Supervision of Public Works was responsible for the integrity of procurement. ${ }^{103}$

Through interventions to improve security and the state of preservation, the project aims to have upgraded the archaeological site of Pompeii by December 2015. The plan consists of five parts: Knowledge, Works in Advanced Planning, Plan for Public Access, Improvements of Services and Communication, Security Plan, and Plan for Reinforcement of Technology and Capacity Building. The General Direction for Antiquities of MiBAC has developed the Plan of Knowledge and at present the first competitions for public contracts have been started. However, the general public wonders whether the interventions can possibly be correctly implemented when, to win the contracts companies have offered discounts of $54 \%$ on the basis of an auction, in view of the fact that, to save time, the criterion

102 Cardone 2011, 6.

${ }^{103}$ Progetto Grande Pompeii, 2012. 
of awarding contracts has been defined as "lowest price" as opposed to the "economically most advantageous offer.”104

But beyond the particular situation of Pompeii, Italian archaeology daily faces another kind of emergency: the need to reconcile the demands of protection with those of urban development. Rescue excavations, especially in the urban environment, are often contrasted to research excavations, which for many years have been undertaken only by universities. In this regard a debate with a political twist has started between Carandini and the world of the superintendencies. The archaeologist criticizes the personal madness of excavating to "save everything” but which often results in a lack of understanding and publication of the data, sometimes impeding any possible continuity of urban life or transformation of the countryside and of cities. Carandini also denounces a failure to use non-invasive instruments and preventive archaeology. In contrast, some archaeologists in superintendencies have defended and defined the situation maintaining the importance of protective actions they have taken and citing recent best practices, including in the area of use and valorization of the archaeological remains. ${ }^{105}$ As is often the case, the truth is to be found somewhere in the middle. Even if it is

${ }^{104}$ Journalist Vincenzo Esposito highlights the issue, noting that all the three auctions have been won by the same contractor, who offered to complete the works with less than $50 \%$ of the estimated costs. See "Grande Progetto Pompei, ribasso oltre il 50 per cento anche nella terza gara,” in Corriere del Mezzogiorno, May 27th, 2013.

105 The controversy arose in connection with a book by Andrea Carandini (Archeologia classica.Vedere il tempo antico con gli occhi del 2000, Torino: Einaudi, 2008) and has gained prominence among specialists and also in the press coverage: see the column by Paolo Conti, “Andrea Carandini: basta «scavomania», non tutto va salvato," in Corriere della Sera, 3 novembre 2008, at 31; and “Osservazioni dei funzionari della Soprintendenza Speciale di Roma, on patrimoniosos.it, 11 November 2008, document available at: http://www.patrimoniosos.it/rsol.php?op=getcomunicato\&id=2875); cfr. Locatelli, D. and L. Malnati. 2009. 
true that rescue excavations all too often reflect a lack of planning, it is also true that in extreme situations, such as Rome, it will be difficult to give them up. However, there is an effort (albeit only in part) to settle these differences through greater awareness of preventive measures, something essential for the exercise of protection, ${ }^{106}$ through new investigative technologies and information systems, which go in the direction of preventive archaeology. Indeed, awareness is the only tool for plans that are as compatible as possible with protection and preservation of cultural and environmental heritage. It necessitates teamwork with other stakeholders (urban planners, architects, etc.) to take into account the needs of all. Therefore rescue archaeology (Development-led Archaeology) and Preventive Archaeology should not be seen as polar opposites. The extremes and deviances of both ought to be controlled and corrected in order to achieve a proper reconstruction and safe guarding not only of individual monuments or sites but of the entire anthropic landscape. ${ }^{107}$ In contrast to the habitual practices of rescue archaeology following casual finds, in Italy preventive archaeology is becoming institutionalized in recent years--not without problems. ${ }^{108}$ Among preventive and precautionary measures, the Cultural Heritage Code (art. 28, c. 4) introduces the possibility of requesting the execution of preventive archaeological tests at the expense of the patron. Preventive evaluation of archaeological impact (ViArc, i.e., Archaeological Impact Assessment) was made official with the law of June 25, 2005, n. 109 and with the Code of

${ }^{106}$ Brogiolo 2012, 271.

${ }^{107}$ Brogiolo 2009, 6.

${ }^{108}$ Maggi 2007 (initially written in 2005) offers an overview of the approach, discussing mainly rescue archaeology rather than preventive archaeology. In fact, regulations and procedures for Archeological Impact Assessment have been issued since 2006. De Caro 2008, at 11 and 16. 
Public Contracts (articles 95 and 96). ${ }^{109}$ The same procedure is not required, however, for projects undertaken by private parties, ${ }^{110}$ for which it is still necessary to have recourse to rescue archaeology. In June, 2012, the General Direction for Antiquities published the "Procedures of Preventive Control" ${ }^{111}$ while awaiting the official formulation of the guidelines foreseen in the Code of Public Contracts. In practical terms, archaeology was aligned with the phases (preliminary, definitive, executed) of the project of a public contract. In the preliminary phase the contracting party will have to produce for the responsible superintendencies the Document of Preventive Archaeological Evaluation, authored by archaeologists with special qualifications on the basis of archival and bibliographical data, site surveys, geomorphological interpretation relative to the possibility of ancient habitation, photographic interpretation (at least in special cases). In the next phase are foreseen geo-diagnostic investigations and archaeological tests. In the absence of archaeological remains, the superintendent issues a final opinion. On the other hand, where the results so warrant, a final phase will be initiated in which proper archaeological excavation on the basis of directives issued by the superintendency and signed by a trained archaeologist appointed by the contracting party. As a result of the results of this last phase, the superintendency will have to evaluate the compatibility of the proposed public works with protection of the archaeological heritage.

In this most brief period of execution which seeks to effect a transition from the phase of emergency to that of prevention, problems and difficulties have not been lacking, partly as a

\footnotetext{
${ }^{109}$ Malnati 2008, 24; Fantin 2013, 154 and 156.

${ }^{110}$ Maggi 2007, 154.

${ }^{111}$ MiBAC, Direzione Generale per le Antichità, Circolare 10/2012 (June 15th): “Procedure di verifica
} preventiva dell'interesse archeologico ai sensi degli artt. 95 e 96 del D. Lgs. 163/2006 e s.m.i. Indicazioni operative in merito alle attvità di progettazione ed esecuzione delle indagini archeologiche.” 
result of entrenched attitudes and the resistance of various interest groups. In the face of best practices and normative commitments, one encounters a depletion of resources which reduces the efficiency of state-led actions of protection. The regulation starts with a definition of the figure of the professional archaeologist, which in Italy has never been precisely defined by law, since it has always referred to public employees and not private persons, thereby penalizing independent archaeologists are underpaid and without rights in rescue excavations. ${ }^{112}$ With this reform, free-lance archaeologists now hope to receive their due. Nevertheless, the questions of the training and professional recognition of the archaeologist remain under discussion, especially in this transitional period.

\section{The Debate about the Professional Archaeologist and the Reorganization of the University System}

In the past decades intense debates regarding the need of a reform of the educational system $^{113}$ and the education and role of archaeologists has arisen in the country. The generation of archaeologists of the Seventies, under the influence of processual archaeology, had for long time discussed the perfect curriculum studiorum. They felt the need of an up-todate methodology and course of studies. In 1992, the next generation of archaeologists held a workshop in Rome, ${ }^{114}$ whose main questions, in terms of course of studies, training and job market in the archaeological field, are still on the present agenda in spite of the recent

\footnotetext{
${ }^{112}$ Malnati 2011, 9.

${ }^{113}$ Romano 1998.

${ }^{114}$ La Laurea non fa l'archeologo 1993.
} 
university reform, whose results are still to be seen. Specifically, and ironically, it is still difficult in Italy to define who is a professional archaeologist, based on the degree earned. ${ }^{115}$

In 1998 the Italian government attempted a reform of the University system, which underwent major changes in the last few years (2007-2010). In order to be consistent with other European structures, facilitating students' exchange, university is now configured as three level steps of studies (first two levels based on credits’ system):

- $\quad$ Three-years laurea triennale (BA); ${ }^{116}$

- $\quad$ Two-years specialized laurea magistrale (having earned this Laurea a student can later attend MA programs);

- $\quad$ Two or Three-years School of specialization or Doctorate (Ph.D.);

In the light, too, of the rules regarding preventive archaeology, the trend seems to be to go in a direction which might be defined as the archaeologist is someone who has completed the level corresponding to the school of specialization. ${ }^{117}$ The university curriculum, even if it is in the process of adjustment, is not capable of giving the archaeologist a practical, professional education. The aspects of study and research are privileged over preparation in the area of protection. In academic curricula, there ought to be attention paid also to the various new related skills needed by the archaeologist, including, notably, training in management. $^{118}$

${ }^{115}$ See, for instance, the recent on-line poll started by CIA (Confederazione Italiana Archeologi): http://www.archeologi-italiani.it/index.php?option=com_poll\&id=21\%3Achi-si-puo-definire-archeologo$\underline{\text { secondo-te\&lang=it }}$

${ }^{116}$ In order to undertake university studies a student must have attended a five-year high school.

${ }^{117}$ Sassatelli 2011, 13.

${ }^{118}$ Cerquetti 2013, 80. 
In order to make the archaeologist the equal of other professionals, several attempts to create a registry or professional organization have been made in the past, but always without success. ${ }^{119}$ One of the consequences is the absence of protection at work in the private sector, insecurity, and inadequate compensation. In contrast with France, which in 2001 created INRAP (Institut National de Recerches Archéologiques Preventives), Italy has not yet ratified the Convention of La Valletta (1992), which foresees payment of the costs of protection as part of the budget of the works realized (public or private) by the patron. This includes the study and publication of the data, which would bring a resulting increase in the job market for archaeologists. Preventive archaeological evaluation process could be only the beginning of the recognition of the professionalism of the archaeologist, but still lacking is a consistent definition of competences, titles, and responsibilities. A few groups of free-lance archaeologists have been working in this direction for several years, and they have formed associations. In particular, here may be mentioned ANA, CIA, and CNAP. ${ }^{120}$ These groups are starting to develop a definition and to obtain official recognition, including through newly proposed laws, of the archaeological profession. In the absence of a professional definition and of qualitative standards, free-lance archaeologists continue to be exploited by the labor market, without protection and adequate pay, and to run the not infrequent risk of seeing the lesser qualified person replacing the more qualified because of the economic interests of the private patron, which stand in conflict with the needs of protection. ${ }^{121}$

${ }^{119}$ See the dossier “L’Albo professionale degli archeologi” in La Laurea non fa l'archeologo 1993.

${ }^{120}$ ANA, Associazione Nazionale Archeologi: http://www.archeologi.org/; CIA, Confederazione Italiana Archeologi: http://www.archeologi-italiani.it/; CNAP, Confederazione Italiana archeologi Professionisti: http://archeologiprofessionisti.wordpress.com/.

${ }^{121}$ Malnati 2011, 9. 
Currently, in Italy, a large number of archaeologists and archaeology students cannot enter the limited job market. Even if many academic positions have been created recently, the number of students overwhelms the available institutional places. The trend which leads to 'privatize' cultural heritage, at least partially, is an additional Damocles' sword for them, unless it will not be accompanied by serious professionalization and adequate value on the ‘private’ market.

\section{Conclusions}

After the first big excavations (Herculaneum 1738, Pompeii 1748), since 1861, the date of the birth of Italy as a unified country, to the present, many things have been modified or revolutionized, in terms of structure, thought, discoveries, needs and perspectives. Between the old-fashioned antiquarian archaeology (Belle Arti) and the modern management of cultural heritage (Beni Culturali) there are almost a hundred and fifty years of development and changes. What does not change is the inner feeling which led to the acknowledgement of Classicality as the basis for identity of European citizens. The past is in the present and in the future of Italians (and Europeans), not only as a manifestation of culture, but also in terms of economy, since the exploitation of archaeological sites, as a tourist attraction, is not to be undervalued. The capitalistic perspective has, however, as always, its own risks, such as the use of archaeology as political propaganda (as in the Fascist era). The history of archaeology in Italy is therefore intertwined with the history of Italy itself. It is also a story of power struggles, money, ideology, and academic battles. The academic world is not, in fact, an ivory tower and Bianchi Bandinelli's example demonstrates this well. Scholars live in their present 
and affect structures and practices. The organization of the Ministry of Cultural Heritage ${ }^{122}$ and the detailed laws and regulations regarding archaeological remains deserve a place in this story as well as the structure of Universities and their courses of studies, the perspectives for the new generation of archaeologists, the associations of volunteers, and the journals and magazines. Archaeology, then, is not only research, in order to interpret the past, but also protection / long-term preservation, and public access (or Educazione al Patrimonio, Heritage Education, as it is nowadays called). In each phase of these three steps (Ricerca, Tutela, and Valorizzazione) archaeologists must be sincerely responsible: the Italian archaeological landscape as a whole (not only sites and objects) should be considered among non-renewable resources and not the property of a country, but an important part of the World heritage.

${ }^{122}$ The Italian Ministry of Cultural Heritage (Ministero dei Beni Culturali) has been created as an independent structure in 1974, detached from the Ministry of Public Education (Ministero della Pubblica Istruzione). Since then it has been modified, even in the name, being now Ministero dei beni e delle attività culturali e del turismo. Recently an augmented autonomy given to the Regions is more and more revising attributions and competencies. 


\section{Appendix 1. Important Italian Archaeologists (from 1861)}

$\begin{array}{ll}\text { Pietro Rosa } & (1810-1891) \\ \text { Giulio Minervini } & (1819-1891) \\ \text { Giovan Battista De Rossi } & (1822-1894) \\ \text { Giuseppe Fiorelli } & (1823-1896) \\ \text { Felice Barnabei } & (1842-1922) \\ \text { Rodolfo Lanciani } & (1845-1929) \\ \text { Adriano Milani } & (1854-1914) \\ \text { Angelo Pasqui } & (1857-1916) \\ \text { Gian Francesco Gamurrini } & (1835-1923) \\ \text { Federico Halberr } & (1857-1930) \\ \text { Giacomo Boni } & (1859-1925) \\ \text { Corrado Ricci } & (1858-1934) \\ \text { Paolo Orsi } & (1859-1935) \\ \text { Alessandro Della Seta } & (1879-1944) \\ \text { Guido Calza } & (1888-1946) \\ \text { Roberto Paribeni } & (1876-1956) \\ \text { Amedeo Maiuri } & (1886-1963) \\ \text { Alessandro Della Seta } & (1879-1944) \\ \text { Pietro Romanelli } & (1889-1982) \\ \text { Salvatore Aurigemma } & (1885-1964) \\ \text { Biagio Pace } & (1889-1955) \\ \text { Paola Zancani Montuoro } & (1901-1987) \\ \text { Doro Levi } & (1898-1991) \\ \text { Quirino Giglioli } & (1886-1956) \\ \text { Giuseppe Lugli } & (1890-1967) \\ \text { Ranuccio Bianchi Bandinelli } & (1900-1975) \\ \text { Nino Lamboglia } & (1912-1977) \\ \text { Paolo Emilio Arias } & (1907-1998) \\ \text { Giovanni Becatti } & (1912-1973) \\ \text { Massimo Pallottino } & (1909-1995) \\ \text { Margherita Guarducci } & (1902-1999) \\ \text { Ferdinando Castagnoli } & (1917-1988) \\ \text { Antonio Cederna } & (1931-1996) \\ \text { Filippo Coarelli } & (1936- \\ \text { Andrea Carandini } & (1937- \\ \text { Mario Torelli } & (1937- \\ \text { Salvatore Settis } & \end{array}$




\section{Appendix 2. The Structure of MiBAC (Ministry of Cultural Heritage and Tourism)}

Created in 1974 as an independent Ministry, separated from the Ministry for Public Education, it first took the name of Ministero per i Beni Culturali e Ambientali, with competencies on cultural heritage and environmental protection. In 1998 the Ministry underwent some changes and competences in other fields (such entertainments and sports) have been later added, changing the name into "Ministero dei beni e delle attività culturali e del turismo" (MiBAC). Fig. 1 shows the current organization chart, highlighting departments, offices and institutions directly or indirectly related to Archaeological Heritage. Worth of mention is the Special Unit of the Carabinieri (Italian Militar Police) that cooperates with the Ministry in order to counteract illicit trade and illegal excavations. The Art Squad (Comando Carabinieri Tutela Patrimonio Culturale) began its activity in 1969, a few years earlier than UNESCO approved the Convention Concerning the Protection of the World Cultural and Natural Heritage (Paris, 1972), and Italy was the first country that had a special Police Department for protecting cultural heritage, currently coordinating other groups of police, such as the Guardia di Finanza - Gruppo Tutela Patrimonio Archeologico. MiBAC is also in charge of all the National Museums. 


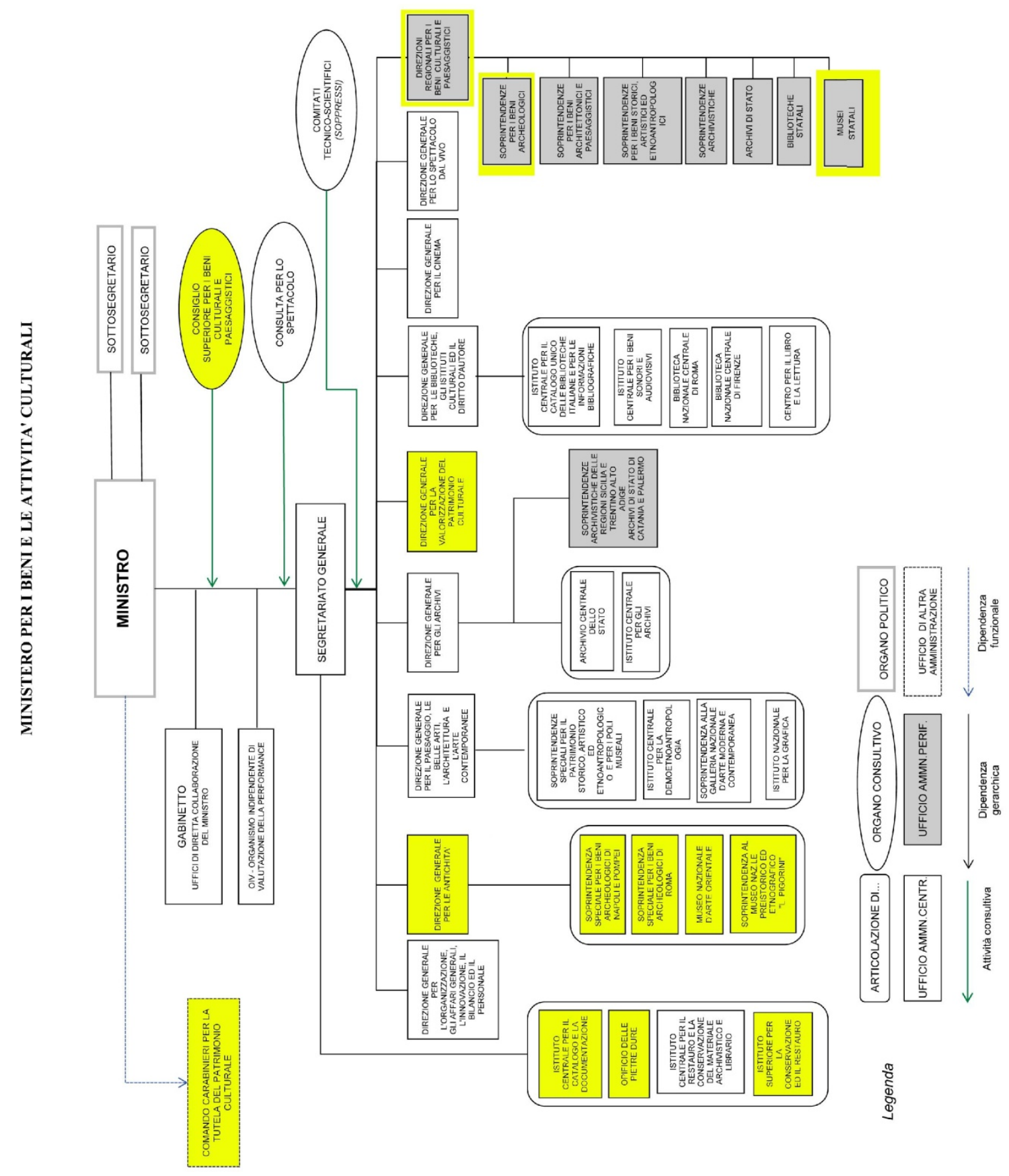

Fig. 1 MiBAC Organization Chart from.

http://www.beniculturali.it/mibac/export/MiBAC/sito-

MiBAC/MenuPrincipale/Ministero/La-struttura-organizzativa/index.html.

Departments related to Archaeology are highlighted in yellow. 
The Superintendencies for Archaeological Heritage are among the peripheral departments of the Ministry; besides those, some Superintendencies for Archaeological Heritage are not directly under MiBAC control, such as no.23 (under the City of Rome), nos. 24-33 (under Autonomous Region of Sicily), no. 34 (under the Autonomous Region of Val d'Aosta), n. 35 (under the Autonomous Province of Trento), and n. 36 (under the Autonomous Province of Bolzano):

1 SOPRINTENDENZA AL MUSEO NAZIONALE PREISTORICO ETNOGRAFICO "L. PIGORINI" Director: Francesco DI GENNARO - Piazza Guglielmo Marconi 14 - 00144 -Roma 2 SOPRINTENDENZA PER I BENI ARCHEOLOGICI DEL FRIULI VENEZIA GIULIA

Director: Luigi FOZZATI - Viale Miramare 9 - 34132 -Trieste 3 SOPRINTENDENZA PER I BENI ARCHEOLOGICI DEL LAZIO Director: Elena CALANDRA - Via Pompeo Magno 2 - 00192 -Roma 4 SOPRINTENDENZA PER I BENI ARCHEOLOGICI DEL MOLISE Director: Alfonsina RUSSO - Via A. Chiarizia 14 - 86100 -Campobasso 5 SOPRINTENDENZA PER I BENI ARCHEOLOGICI DEL PIEMONTE E DEL MUSEO ANTICHITÀ EGIZIE

Director: Egle MICHELETTO - Piazza San Giovanni 2 - 10122 -Torino 6 SOPRINTENDENZA PER I BENI ARCHEOLOGICI DEL VENETO Director: Vincenzo TINE' - Via Aquileia 7 - 35139 -Padova 7 SOPRINTENDENZA PER I BENI ARCHEOLOGICI DELL'ABRUZZO Director: Fabrizio MAGANI -Via degli Agostiniani 14 - 66100 -Chieti 8 SOPRINTENDENZA PER I BENI ARCHEOLOGICI DELL'EMILIA ROMAGNA Director: Filippo Maria GAMBARI - Via Belle Arti 52 - 40126 -Bologna 9 SOPRINTENDENZA PER I BENI ARCHEOLOGICI DELL'ETRURIA MERIDIONALE Director: Alfonsina RUSSO - P.le di Villa Giulia 9 - 00196 -Roma 10 SOPRINTENDENZA PER I BENI ARCHEOLOGICI DELL'UMBRIA Director: Mario PAGANO - Piazza Partigiani - 06121 -Perugia 11 SOPRINTENDENZA PER I BENI ARCHEOLOGICI DELLA BASILICATA Direttore: Antonio DE SIENA - via Andrea Serrao 1 - Palazzo Loffredo - 85100 -Potenza 12 SOPRINTENDENZA PER I BENI ARCHEOLOGICI DELLA CALABRIA Director: Simonetta BONOMI - Via Domenico Romeo - 89125 -Reggio di Calabria 13 SOPRINTENDENZA PER I BENI ARCHEOLOGICI DELLA LIGURIA Director: Bruno MASSABO' - Via Balbi 10 - 16126 -Genova 14 SOPRINTENDENZA PER I BENI ARCHEOLOGICI DELLA LOMBARDIA

Director: Raffaella POGGIANI - Via E. De Amicis 11 - 20123 -Milano 15 SOPRINTENDENZA PER I BENI ARCHEOLOGICI DELLA PUGLIA Director: LA ROCCA - Via Duomo 33 - 74100 -Taranto 16 SOPRINTENDENZA PER I BENI ARCHEOLOGICI DELLA TOSCANA Director: Andrea PESSINA - Via della Pergola 65 - 50121 -Firenze 17 SOPRINTENDENZA PER I BENI ARCHEOLOGICI DELLE MARCHE Director: Mario PAGANO (interim) - Via Birarelli 18 - 60121 -Ancona 18 SOPRINTENDENZA PER I BENI ARCHEOLOGICI DI SALERNO AVELLINO BENEVENTO E CASERTA

Director: Adele CAMPANELLI - Via Trotula de Ruggiero 6-7 - 84100 -Salerno 19 SOPRINTENDENZA PER I BENI ARCHEOL. PROVINCE DI CAGLIARI E ORISTANO

Director: Marco Edoardo MINOJA - Piazza Indipendenza 7 - 09124 -Cagliari 20 SOPRINTENDENZA PER I BENI ARCHEOL. PROVINCE DI SASSARI E NUORO Director: Marco Edoardo MINOJA (interim) - Piazza Sant. Agostino 2 - 07100 -Sassari 
21 SOPRINTENDENZA SPECIALE PER I BENI ARCHEOLOGICI DI NAPOLI E POMPEI

Director: Teresa Elena CINQUANTAQUATTRO - Piazza Museo 19 - 80135 -Napoli

22 SOPRINTENDENZA SPECIALE PER I BENI ARCHEOLOGICI DI ROMA

Director: Mariarosaria BARBERA - Piazza dei Cinquecento 67 - 00185 -Roma

23 SOVRAINTENDENZA COMUNALE AI BENI CULTURALI DEL COMUNE DI ROMA

Director: Claudio Parisi Presicce - Piazza Lovatelli, 35 - 00186 ROMAIt is autonomous from the Ministry and dependent from the City of Rome since it is the heir of the Commissione Archeologica Comunale; it maintains its unique status because of the peculiarity of Rome.

24-33 SOPRINTENDENZE PER I BENI CULTURALI E AMBIENTALI DELLA REGIONE SICILIANA

Sicily has, by the Italian Constitutional Chart, a special autonomy and the Suprintendencies are under the authority of the Regional Parliament (art. 8 L. Jan 22, 2004, n. 42). In Sicily there are ten Suprintendencies for Cultral Heritage, each with a department for archaeological heritage (Agrigento, Caltanissetta, Catania, Enna, Messina, Palermo, Ragusa, Siracusa, Trapani, and the Suprintendency of the Sea, located at Palermo) 34 SOPRINTENDENZA PER I BENI E LE ATTIVITÀ CULTURALI REGIONE VAL D’AOSTA

Val d'Aosta has, by the Italian Constitutional Chart, a special autonomy and administrates directly this Suprintendency (art. 8 L. Jan 22, 2004, n. 42) 35 SOPRINTENDENZA PER I BENI ARCHITETTONICI ED ARCHEOLOGICI DELLA PROVINCIA DI TRENTO

The autonomous Province of Trento administrates directly this Soprintendency (art. 8 L. Jan 22, 2004, n. 42) 36 RIPARTIZIONE BENI CULTURALI DELLA PROVINCIA DI BOLZANO

The autonomous Province of Bolzano administrates directly this Soprintendency (art. 8 L. Jan 22, 2004, n. 42)

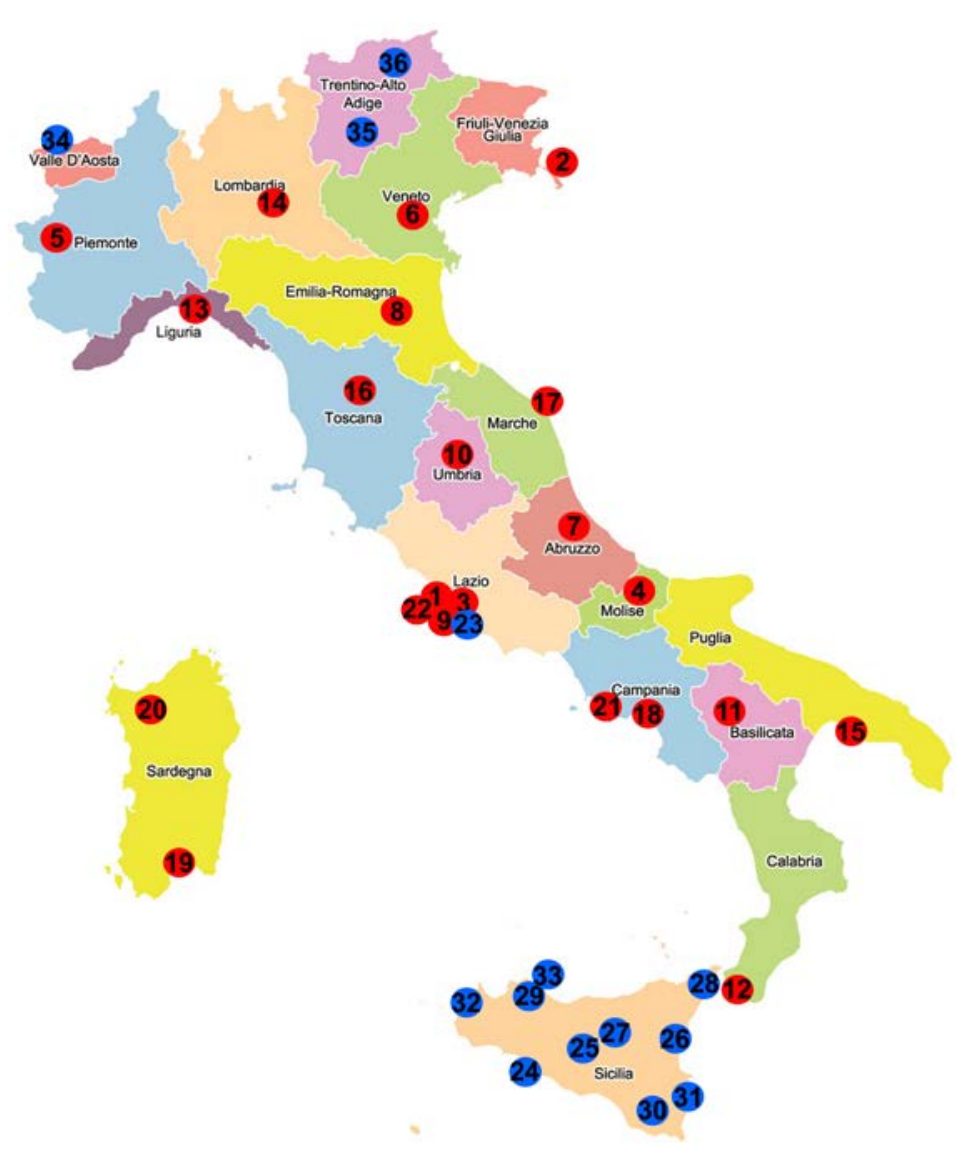

Fig. 2. Superintendencies for Archaeological Heritage; those depending from MIBAC

are listed in red; those depending from other institutions are listed in blue. 
Having in mind such a complex system and the peculiar richness of archaeological heritage clear becomes how economical resources available are absolutely inadequate, especially when compared with percentages of State Budget and GDP, and decreasing every year as shown in the following fig. 3 .

\begin{tabular}{|c|c|c|c|c|}
\hline \multicolumn{5}{|c|}{ MiBAC extimates and final balance } \\
\hline YEAR & _аввас вUDGE: & \% STATE BUDGEI & $\%$ GDP & FINALL. \\
\hline 2000 & $2,102,267,762$ & $0.39 \%$ & $0.18 \%$ & $2,398,719,341$ \\
\hline 2001 & $2,240,982,404$ & $0.37 \%$ & $0.18 \%$ & $2,707,783,742$ \\
\hline 2002 & 2,114,531,106 & $0.35 \%$ & $0,16 \%$ & $2,478,989,157$ \\
\hline 2003 & $2,116,173,301$ & $0.32 \%$ & $0.16 \%$ & $2,583,527,910$ \\
\hline 2004 & $2,196,711,000$ & $0.34 \%$ & $0.16 \%$ & $2,405,206,549$ \\
\hline 2005 & $2,200,625,507$ & $0.34 \%$ & $0.15 \%$ & $2,408,291,149$ \\
\hline 2006 & $1,859,838,752$ & $0.29 \%$ & $0.13 \%$ & $2,226,883,335$ \\
\hline 2007 & 1,987,001,163 & $0.29 \%$ & $0.13 \%$ & 2,230,275,797 \\
\hline 2008 & $2,037,446,020$ & $0.28 \%$ & $0.13 \%$ & $2,116,328,608$ \\
\hline 2009 & $1,718,595,000$ & $0.23 \%$ & $0.11 \%$ & $1,937,309,228$ \\
\hline 2010 & $1,710,407,803$ & $0.21 \%$ & $0.11 \%$ & $1,795,542,456$ \\
\hline 2011 & $1,425,036,650$ & $0.19 \%$ & $0.11 \%$ & $1,807,888,266$ \\
\hline 2012 & $1,687,429,482$ & $0.22 \%$ & - & - \\
\hline 2013 & $1,546,779,172$ & $0.20 \%$ & _ & - \\
\hline
\end{tabular}

Fig. 3. From Culture in Italy, basic figures 2012 (Minicifre 2013), available at:

http://www.beniculturali.it/mibac/export/UfficioStudi/sito-

UfficioStudi/Contenuti/Pubblicazioni/Volumi/Volumi-

pubblicati/visualizza_asset.html_1671994226.html 


\section{Appendix 3. Important Laws and Regulation Concerning Cultural Heritage in Italy}

Law 1089, June 1st, 1939.** Tutela delle cose d'interesse artistico e storico (Protection of items of artistic and historical interest).

Law 1497, June 29th, 1939.** Protezione delle bellezze naturali (Protection of the beauty of nature).

Law 1062, November 20th, 1971.** Norme penali sulla contraffazione od alienazione di opere d'arte (Criminal law on counterfeiting or sale of works of art).

Law 487, August 8th, 1972. Nuove norme sulla esportazione delle cose di interesse artistico e archivistico di cui alla legge 1 giugno 1939, n. 1089, e al DPR 30 settembre 1963, n. 1409 (New regulations on the export of artistic and archival items defined by Law no. 1089/1939 and Presidential Decree no. 1409/1963).

Decree-Law 657, December 14th, 1974 / Law 5, January 29th, 1975. Istituzione del Ministero per $i$ beni culturali e per l'ambiente (Establishment of the Ministry for Cultural and Natural Heritage).

D.P.R. 805, December 3rd, 1975.** Organizzazione del Ministero per i beni culturali e ambientali (Presidential Decree: Organization of the Ministry for cultural and natural heritage).

D. Lgs. 368, October 20th, 1998. Istituzione del Ministero per i beni e le attività culturali (Legislative Decree: Establishment of the Ministry for cultural heritage and activities).

D. Lgs. 29 ottobre 1999, n. 490.** TESTO UNICO delle disposizioni legislative in materia di beni culturali e ambientali (Legislative Decree: Consolidation bill on regulations concerning cultural and natural heritage)

D.P.R. 441, December 29th, 2000.** Regolamento recante norme di organizzazione del Ministero per i Beni e le Attività Culturali (Presidential Decree: Regulations for the organization of the Ministry of cultural heritage and activities).

D.M. May 10th, 2001. Ministero per i Beni e le Attività Culturali. Atto di indirizzo sui criteri tecnicoscientifici e sugli standard di funzionamento e sviluppo dei musei (Ministerial Decree by MIBAC. Guidelines on technical-scientific criteria and management standards of museums).

D. Lgs. 3, January 8th, 2004. Riorganizzazione del Ministero per i beni e le attività culturali (Legislative Decree: Reorganization of the Ministry of cultural heritage and activities).

D. Lgs, January 22th, 2004. Codice dei Beni Culturali e del Paesaggio, ai sensi dell'articolo 10 della legge 6 luglio 2002, n. 137. e s.m.i. (aggiornato al D.L. 21 giugno 2013, n. 69) Legislative Decree: "Law on Cultural and Natural Heritage" pursuant to Article 10, Law 137, July 6th, 2002, and further modifications and integrations (updated to Decree-Law 69, June 21, 2013).

D.P.R. 173, June 8th, 2004.** Regolamento di organizzazione del Ministero per i beni e le attività culturali (Presidential Decree: Regulations for the organization of Ministry of cultural heritage and acitivities).

D.M. August 5th, 2004. Ministero per i Beni e le Attività Culturali. Delega di funzioni ai direttori regionali per i beni culturali e paesaggistici. (Ministerial Decree by MIBAC. Delegation of functions to the regional directors for cultural heritage and landscape).

Law 109, June 25, 2005, art.2 ter. Verifica preventiva dell'interesse archeologico (Preventive archaeological assessment). 
D.M. May 31, 2006. Ministero dell'Istruzione dell'Università e della Ricerca. Riassetto delle Scuole di specializzazione nel settore della tutela, gestione e valorizzazione del patrimonio culturale. (Ministerial Decree by the Ministry for Education, University and Scientific Research. Reorganization of Graduate Schools of specialization in the field of protection, management, and valorization of cultural heritage).

Law 77, February 20th, 2006. Misure speciali di tutela e fruizione dei siti italiani di interesse culturale, paesaggistico e ambientale, inseriti nella «lista del patrimonio mondiale», posti sotto la tutela dell'UNESCO. (Special regulations for protection and fruition of the Italian cultural, landscape and environment heritage sites, included in the 'World Heritage List,' under the protection of UNESCO).

D. Lgs. 156, March 24th, 2006. Disposizioni correttive ed integrative al decreto legislativo 22 gennaio 2004, n. 42, in relazione ai beni culturali (Legislative Decree: Corrections ad integrations to the Law on Cultural Heritage).

D. Lgs. 163, April 12 ${ }^{\text {th }}$, 2006. Artt. 95-96 and 197-205. Codice dei contratti pubblici relativi a lavori, servizi e forniture, s.m.i. (Legislative Decree. Public Procurement Law, further modifications and integrations).

D.P.R. 233, November 26th, 2007. Regolamento di riorganizzazione del Ministero per i beni e le attività culturali s.m.i. (Presidential Decree: Regulations for the reorganization of Ministry of cultural heritage and activities, and further integrations and modifications).

D.M. January 29th, 2008. Ministero per i Beni e le Attività Culturali. Modalità di affidamento a privati e di gestione integrata dei servizi aggiuntivi presso istituti e luoghi della cultura. (Ministerial Decree by MIBAC. Procedures for awarding integrated management and for service concessions in the field of cultural heritage to private holdings)-

D.P.R. 91, July 2nd, 2009. Regolamento recante modifiche ai decreti presidenziali di riorganizzazione del Ministero e di organizzazione degli Uffici di diretta collaborazione del Ministro per i beni e le attività culturali (Presidential Decree amending previous regulations on the organization of the Ministry of cultural heritage and activities).

C.M. 10-2012 and related attachments 1-2-2 $\underline{3}$ Verifica preventiva dell'interesse archeologico. Indicazioni operative (Ministerial Circular by Genral Direction for Antiquities at MIBAC. Preventive archaeological assessment. Temporary Practical Guidelines)

D. M. December 19th, 2012 Ministero per i Beni e le Attività Culturali. Approvazione delle norme tecniche e linee guida in materia di sponsorizzazioni di beni culturali e di fattispecie analoghe o collegate. (Ministerial Decree by MIBAC. Standards and guidelines for sponsorship in the field of cultural heritage).

Law 71, June 24th, 2013, art. 1, cc. 2 and 3. Trasferimento di funzioni in materia di turismo al MIBAC, con conseguente modifica del nome del ministero (Transfer of functions in the field of tourism to MIBAC, resulting in changing the name of the Ministry).

** no longer in force, as superseded by subsequent regulations. 
Appendix 4. Synoptic table of facts

\begin{tabular}{|c|c|c|c|c|c|}
\hline Chronology & People & Facts & $\begin{array}{l}\text { Institutions / } \\
\text { Laws }\end{array}$ & Academic World & $\begin{array}{l}\text { Public / } \\
\text { publications }\end{array}$ \\
\hline $\begin{array}{l}\text { XV - XVI cent. } \\
\text { Recovery of } \\
\text { Classical Past as a } \\
\text { model }\end{array}$ & $\begin{array}{l}\text { Lorenzo } \\
\text { Valla } \\
\text { Flavio } \\
\text { Biondo } \\
\text { Ciriaco de' } \\
\text { Pizzicolli } \\
\text { Pirro } \\
\text { Ligorio } \\
\text { Onofrio } \\
\text { Panvinio }\end{array}$ & $\begin{array}{l}1471 \text { nucleus of } \\
\text { the Capitoline } \\
\text { Museums } \\
1506 \text { discovery of } \\
\text { the Laoocont } \\
\text { Museum of the } \\
\text { Belvedere } \\
\text { (Vatican) } \\
\text { Treasure hunt } \\
\text { (Hadrian's Villa, } \\
\text { Palatine Hill, } \\
\text { etc...) }\end{array}$ & $\begin{array}{l}1534 \text { Commission } \\
\text { for Antiquities } \\
\text { (Papal State) }\end{array}$ & & $\begin{array}{l}\text { Books, notes, } \\
\text { pamphlets, } \\
\text { drawings } \\
\text { (low diffusion) }\end{array}$ \\
\hline $\begin{array}{l}\text { XVII-XVIII cent. } \\
\text { Antiquarians and } \\
\text { erudition }\end{array}$ & $\begin{array}{l}\text { Antonio } \\
\text { Bosio } \\
\text { Raffaele } \\
\text { Fabretti } \\
\text { Giovan } \\
\text { Battista } \\
\text { Piranesi } \\
\text { Giambattista } \\
\text { Nolli }\end{array}$ & $\begin{array}{l}1709 \\
\text { Identification of } \\
\text { Herculaneum } \\
1720 \text { Palatine Hill } \\
1734 \text { Capitolini } \\
\text { Museums opened } \\
1738 \text { Excavations } \\
\text { at Herculaneum } \\
1748 \text { Excavations } \\
\text { at Pompeii } \\
\text { 1770 Roman } \\
\text { Forum }\end{array}$ & $\begin{array}{l}1755 \text { Kingdom of } \\
\text { Naples law: need } \\
\text { of a special } \\
\text { permission for } \\
\text { excavations }\end{array}$ & $\begin{array}{l}1727 \text { Accademia } \\
\text { Etrusca di } \\
\text { Cortona } \\
1735 \text { Società } \\
\text { Colombaria di } \\
\text { Firenze } \\
1738 \text { Reale } \\
\text { Accademia } \\
\text { Ercolanese } \\
1740 \text { Accademia } \\
\text { di Antichità } \\
\text { Profane }\end{array}$ & $\begin{array}{l}\text { Maps, books, } \\
\text { drawings } \\
\text { (low diffusion) }\end{array}$ \\
\hline $\begin{array}{l}\text { End of XVIII cent. } \\
-1861 \\
\text { Archaeology as } \\
\text { Art History }\end{array}$ & $\begin{array}{l}\text { Ennio } \\
\text { Quirino } \\
\text { Visconti } \\
\text { Carlo Fea } \\
\text { Bartolomeo } \\
\text { Borghesi } \\
\text { Antonio } \\
\text { Nibby } \\
\text { Luigi } \\
\text { Canina }\end{array}$ & $\begin{array}{l}\text { Excavation on } \\
\text { Etruscan and } \\
\text { other italic sites }\end{array}$ & $\begin{array}{l}\text { 1802-1820 Papal } \\
\text { State's Law for } \\
\text { preserving } \\
\text { antiquities } \\
\text { Commissione di } \\
\text { Belle Arti } \\
1829 \text { International } \\
\text { Institute of } \\
\text { Archaeological } \\
\text { Correspondence } \\
\text { 1839 Edict of the } \\
\text { King of Naples }\end{array}$ & $\begin{array}{l}\text { Most of the } \\
\text { Universities have } \\
\text { chairs on } \\
\text { antiquities by } \\
\text { now, mostly held } \\
\text { by 'antiquarians.' }\end{array}$ & $\begin{array}{l}\text { Maps, books, } \\
\text { drawings } \\
\text { (low diffusion) }\end{array}$ \\
\hline
\end{tabular}




\begin{tabular}{|c|c|c|c|c|c|}
\hline Chronology & People & Facts & $\begin{array}{l}\text { Institutions / } \\
\text { Laws }\end{array}$ & Academic World & $\begin{array}{l}\text { Public / } \\
\text { publications }\end{array}$ \\
\hline $\begin{array}{l}1861 \text { - } 1922 \\
\text { Philological } \\
\text { Archaeology } \\
\text { German influence } \\
\text { Idealism vs } \\
\text { Positivism }\end{array}$ & $\begin{array}{l}\text { Rosa } \\
\text { De Rossi } \\
\text { Fiorelli } \\
\text { Barnabei } \\
\text { Lanciani } \\
\text { (FUR) } \\
\text { Milani } \\
\text { Pasqui } \\
\text { Boni } \\
\text { Ricci } \\
\text { Orsi }\end{array}$ & $\begin{array}{l}\text { Excavations in } \\
\text { Rome } \\
\text { Excavations in the } \\
\text { Roman Forum } \\
\text { (Boni: "Il metodo } \\
\text { dello scavo") } \\
\text { Excavations in } \\
\text { Pompeii } \\
\text { Excavations in } \\
\text { Sicily and in } \\
\text { Calabria } \\
\text { (Prehistoric } \\
\text { excavations in } \\
\text { Italy) } \\
\text { 1884 Italian } \\
\text { research in Crete } \\
\text { Greece } \\
\text { Libya and } \\
\text { Cyrenaic } \\
\text { Rhodes }\end{array}$ & $\begin{array}{l}1870 \\
\text { Soprintendenza } \\
\text { agli Scavi di } \\
\text { Antichità } \\
1872 \\
\text { Commissione } \\
\text { Archeologica } \\
\text { Comunale } \\
1875 \text { Direzione } \\
\text { Generale degli } \\
\text { scavi e dei musei } \\
\text { (MPI) } \\
\text { 1907 } \\
\text { Superintendencies } \\
\text { 1909 National } \\
\text { Law on Historic } \\
\text { heritage } \\
\text { 1918 Istituto } \\
\text { Nazionale di } \\
\text { Archeologia e } \\
\text { Storia dell’Arte }\end{array}$ & $\begin{array}{l}1861 \text { Fiorelli Prof. } \\
\text { at Naples } \\
1866 \\
\text { Archaeological } \\
\text { School of } \\
\text { Pompeii } \\
\text { 1874 Accademia } \\
\text { dei Lincei: section } \\
\text { Humanities } \\
\text { 1876 Scuola } \\
\text { Superiore di } \\
\text { Archeologia } \\
\text { 1882 Lanciani } \\
\text { Prof of Roman } \\
\text { Topography in } \\
\text { Rome } \\
\text { 1890 Chair of } \\
\text { Classical } \\
\text { Archaeology at } \\
\text { the Univ. of } \\
\text { Rome: E. Löwy } \\
\text { (1892 Gypsotek) } \\
\text { 1909 Italian } \\
\text { Archaeological } \\
\text { School at Athens }\end{array}$ & $\begin{array}{l}\text { 1861-65 Giornale } \\
\text { degli scavi } \\
1872 \text { Bull. Comm. } \\
\text { Arch. Com. Roma } \\
1873 \text { Rivista di } \\
\text { filologia classica } \\
\text { 1877 Notizie degli } \\
\text { scavi di antichità } \\
1889 \text { National } \\
\text { Roman Museum } \\
\text { (Terme and Villa } \\
\text { Giulia) } \\
\text { 1906 Bollettino } \\
\text { d'Arte } \\
\text { 1907 Ausonia } \\
\text { 1911 } \\
\text { Archaeological } \\
\text { exhibition in Rome } \\
\text { 1914 Annual of the } \\
\text { School of Athens }\end{array}$ \\
\hline $\begin{array}{l}\text { 1922-1945 } \\
\text { The Fascist Era } \\
\text { Archaeology as } \\
\text { study of ancient } \\
\text { civilization }\end{array}$ & $\begin{array}{l}\text { Della Seta } \\
\text { Doro Levi } \\
\text { Giglioli } \\
\text { Gismondi } \\
\text { Paribeni } \\
\text { Maiuri } \\
\text { Calza } \\
\text { Lamboglia }\end{array}$ & $\begin{array}{l}\text { Excavations of } \\
\text { the Imperial Fora } \\
\text { Excavation of } \\
\text { Augustan } \\
\text { Mausoleum } \\
\text { Rhodes, Albania, } \\
\text { Libia, Greece, } \\
\text { Crete, Egypt. } \\
\text { Surveys in Turkey } \\
\text { Pompeii, } \\
\text { Herculaneum } \\
\text { Ostia }\end{array}$ & $\begin{array}{l}1939 \text { National } \\
\text { Law on } \\
\text { archaeological, } \\
\text { artistic and } \\
\text { historic } \\
\text { monuments and } \\
\text { sites }\end{array}$ & $\begin{array}{l}1923 \text { National } \\
\text { Council for } \\
\text { Research (CNR) } \\
\text { Giglioli for } 20 \\
\text { years chair of } \\
\text { Archaeology in } \\
\text { Rome }\end{array}$ & $\begin{array}{l}1927 \text { Museum of } \\
\text { Roman Empire } \\
1927 \text { Studi Etruschi } \\
1929 \text { Rivista } \\
\text { dell'Istituto } \\
\text { Nazionale di } \\
\text { Archeologia e } \\
\text { Storia dell'Arte } \\
\text { Roma } \\
\text { Capitolium } \\
\text { Urbe }\end{array}$ \\
\hline $\begin{array}{l}\text { After II WW to } \\
\text { the Sixties } \\
\text { Various trends, to } \\
\text { the "folk-art" } \\
\text { (Bandinelli), } \\
\text { beginning of the } \\
\text { study of the } \\
\text { pottery as an } \\
\text { indicator of } \\
\text { chronology and } \\
\text { economy }\end{array}$ & $\begin{array}{l}\text { Bianchi } \\
\text { Bandinelli } \\
\text { Pallottino } \\
\text { Becatti }\end{array}$ & Albintimilium & $\begin{array}{l}1945-47 \\
\text { Bandinelli at the } \\
\text { Direzione } \\
\text { Generale }\end{array}$ & $\begin{array}{l}1945 \\
\text { Associazione } \\
\text { Internazionale di } \\
\text { Archeologia } \\
\text { Classica } \\
\text { 1964 Società } \\
\text { degli Archeologi } \\
\text { Italiani }\end{array}$ & $\begin{array}{l}\text { 1946 Fasti } \\
\text { Archeologici } \\
\text { 1946 La Parola del } \\
\text { Passato } \\
1949 \text { Archeologia } \\
\text { Classica } \\
1958 \text { I vol. } \\
\text { Enciclopedia } \\
\text { dell’Arte Antica } \\
\text { 1958 I International } \\
\text { Conference of } \\
\text { Classical } \\
\text { Archaeology } \\
\text { (AIAC) } \\
\text { 1967 Dialoghi di } \\
\text { Archeologia }\end{array}$ \\
\hline
\end{tabular}




\begin{tabular}{|c|c|c|c|c|c|}
\hline Chronology & People & Facts & $\begin{array}{l}\text { Institutions / } \\
\text { Laws }\end{array}$ & Academic World & $\begin{array}{l}\text { Public / } \\
\text { publications }\end{array}$ \\
\hline $\begin{array}{l}\text { Use of technology } \\
\text { Need of a } \\
\text { multidisciplinary } \\
\text { team } \\
\text { High } \\
\text { specialization } \\
\text { iconology } \\
\text { total history (the } \\
\text { big picture) } \\
\text { archaeology of the } \\
\text { production } \\
\text { underwater } \\
\text { archaeology } \\
\text { maritime } \\
\text { archaeology }\end{array}$ & $\begin{array}{l}\text { Carandini } \\
\text { Torelli } \\
\text { Coarelli } \\
\text { Zevi }\end{array}$ & $\begin{array}{l}\text { 1973 Carthage } \\
\text { 1976-81 } \\
\text { Settefinestre } \\
1981 \text { Crypta Balbi } \\
\text { Surveys } \\
\text { (Tuscany, } \\
\text { Latium) } \\
\text { Rescue } \\
\text { excavations } \\
\text { “Small dig” } \\
\text { Imperial Fora } \\
\text { Pompeii }\end{array}$ & $\begin{array}{l}\text { 1974 Ministery of } \\
\text { Cultural Heritage } \\
1975 \text { ICCD } \\
\text { Istituto per il } \\
\text { Catalogo e la } \\
\text { Documentazione } \\
\text { 1998-2013 } \\
\text { Laws drastically } \\
\text { changed } \\
\text { The structure of } \\
\text { the Ministery and } \\
\text { the related } \\
\text { suprintedencies is } \\
\text { drastically } \\
\text { changing } \\
\text { The need of } \\
\text { private } \\
\text { sponsorship and } \\
\text { the intervention of } \\
\text { private holdings } \\
\text { in the } \\
\text { management of } \\
\text { archaeological } \\
\text { heritage } \\
\text { Public } \\
\text { Archaeology }\end{array}$ & $\begin{array}{l}1993 \text { Italian } \\
\text { Association of } \\
\text { Archaeometry } \\
\text { 1998-2004 } \\
\text { University system } \\
\text { drastically } \\
\text { changed }\end{array}$ & $\begin{array}{l}\text { Forma Italiae } \\
\text { Exhibitions } \\
\text { TV documentaries } \\
\text { (Time machine, } \\
\text { Ulysses or the taste } \\
\text { of discoveries) } \\
\text { Attractive sites } \\
\text { presentation } \\
\text { Popular magazines } \\
\text { (Archeo, } \\
\text { Archeologia Viva, } \\
\text { L’Archeologo } \\
\text { subacqueo, Forma } \\
\text { Urbis) } \\
\text { 1989 Bollettino di } \\
\text { Archeologia } \\
\text { Computer approach } \\
\text { (CAA Conference: } \\
\text { Computer } \\
\text { application in } \\
\text { Archaeology) } \\
\text { 2000 Orizzonti } \\
\text { 2003 Fastionline } \\
\text { 2003 Archaeologiae } \\
\text { ArcheoMedia: } \\
\text { rivista archeologica } \\
\text { italiana } \\
\text { Archeogate }\end{array}$ \\
\hline
\end{tabular}




\section{Bibliographical References}

Alibrandi, T. and P. Ferri. 1988. Il diritto dei beni culturali. Roma: NIS.

Alibrandi, T. and P. Ferri. 1995. I beni culturali e ambientali. Milano: Giuffrè.

Arias, P. E. 1976. Quattro archeologi del nostro secolo. Paolo Orsi, Biagio Pace, Alessandro della Seta, Ranuccio Bianchi-Bandinelli. Pisa: Giardini.

Archeologia del Paesaggio 1992. IV Ciclo di Lezioni sulla ricerca applicata in Archeologia (Certosa di Pontignano 1991), edited by M. Bernardi, Firenze: All’Insegna del Giglio.

Attema P., Burgers, G., van Joolen, E., van Leusen, M., and Mater, B. (eds.), 2002. New Development in Italian Landscape Archaeology, BAR International Series 1091, Oxford.

Barbanera, M. 1998. L'archeologia degli italiani. Rome: Editori Riuniti.

Barbanera, M. 2000. “Idee per una storia dell’Archeologia Classica in Italia dalla fine del Settecento al Dopoguerra." In Archeologia Teorica. X Ciclo di Lezioni sulla Ricerca Applicata in Archeologia (Certosa di Pontignano, Siena, 9-14 agosto 1999), edited by N. Terrenato, 39-56. Firenze: All’Insegna del Giglio.

Barker G.,1995. A Mediterranean Valley: Landscape Archaeology and Annales History in the Biferno Valley and The Biferno Valley Survey: The Archaeological and Geomorphological Record, Leicester University.

Bianchi Bandinelli, R. 1974. AA., BB. AA. e B.C. L'Italia storica e artistica allo sbaraglio. Bari: De Donato.

Bianchi Bandinelli, R. 1976. Introduzione all'archeologia classica come storia dell'arte antica. Bari: Laterza. 
Biondo, F. 1527. De Roma instaurata libri tres ad Eugenium, iiii, pontificem maximum. Blondi Flauii de Italia illustrata. Turin.

Biondo, F. 1531. De Roma triumphante libri decem. Basil.

Bonacchi, C. 2009, Archeologia Pubblica in Italia: origini e prospettive di un nuovo settore disciplinare, “Ricerche Storiche”, XXXIX 2-3, 329-349.

Boni, G. 1901. “Il metodo negli scavi archeologici.” Nuova Antologia 178: 312-327.

Boni, G. 1912. “Il ‘Metodo’ nelle esplorazioni archeologiche.” Rome: Calzone. Extract from BdA 7 (1913), n. 1-2.

Bozóki-Ernyey, K. (ed.) 2007. European Preventive Archaeology (Papers of the EPAC Meeting, Vilnius 2004) Budapest: Demax.

Bray 2013. Hearing of Minister Bray (MiBAC) at the Italian Parliament, on May 23, 2013 (Culture Commissions) documents available at: http://www.beniculturali.it/mibac/export/MiBAC/sito$\underline{\text { MiBAC/Contenuti/Ministero/LegislaturaCorrente/Massimo- }}$ $\underline{\text { Bray/Audizioni/visualizza_asset.html_2064365709.html }}$

Brogiolo, G.P. 2009, "La tutela dei paesaggi storici tra archeologia preventiva e archeologia d'emergenza.” In Atti del V Congresso Nazionale di Archeologia Medievale. 3-6 edited by P. Favia and G. Volpe. Florence: All’Insegna del Giglio.

Brunelli, M. 2013, Archeologi educatori. Attuali tendenze per un'archeologia educativa in Italia, tra heritage education e public archaeology. "Il Capitale Culturale. Studies on the Value of Cultural Heritage” 7: 11-32

Calza, G., G. Becatti, I. Gismondi, G. De Angelis D’Ossat, and H. Bloch. 1953. Topografia Generale. Scavi di Ostia 1. Roma: Libreria dello Stato. 
Cambi, F., Terrenato N., 1994. Introduzione all’Archeologia dei Paesaggi, Roma: NIS. Campana, S., Piro, S. (eds.) 2009, Seeing the Unseen. Geophysics and Landscape Archaeology, London 2009.

Capolavori dell'Archeologia. Recuperi, Ritrovamenti, Confronti, (Rome, Castel Sant’Angelo, May 20th - November 5th 2013), Exhibition Catalogue, 2013, Rome: Gangemi.

Carandini, A., ed. 1985. Settefinestre. Una villa schiavistica nell'Etruria romana. Modena: Panini.

Carandini, A. 1991. Storie dalla terra. Torino: Einaudi.

Cardone, A. 2011. "Le ordinanze di protezione civile e il "governo straordinario" dei beni culturali: dal terremoto di L’Aquila alle celebrazioni per il $150^{\circ}$ anniversario dell’Unità d’Italia.” Osservatoriosullefonti.it fasc. 3/2011: 1-7.

Cederna, A. 1979. Mussolini urbanista: lo sventramento di Roma negli anni del consenso. Rome: Laterza.

Cerquetti, M. 2013. “A scuola di archeologia? Il management dei beni culturali dalla ricerca alla formazione universitaria. Note a margine di un dibattito in corso," Il capitale culturale, VII (2013): 65-88.

Ciriaco de’ Pizzicolli. 1742. Kyriaci Anconitani Itinerarium nunc primum ex ms. cod. in lucem erutum ex bibl. illus. clarissimique baronis Philippi Stosch. Editionem recensuit, animadversionibus, ac praefatione illustravit, nonnullisque ejusdem Kyriaci epistolis partim editis, partim ineditis locupletavit Laurentius Mehus.

Ciriaco de’ Pizzicolli. 1747. Inscriptiones, seu Epigrammata graeca et latina reperta per Illyricum a Cyriaco Anconitano apud Liburniu, designatis locis, ubi quaeque inventa sunt cum descriptione itineris. Rome. 
Coche de La Ferté, E. 1958. “Archeologia Cristiana.” EAA II:557-561.

Coleman, C. B., ed. 1922. De falso credita et ementita Constantini donatione declaratio. New Haven: Yale University Press 1922. Della Seta, A. 1913. “L’archeologia dai Greci al Winckelmann e a noi.” Nuova Antologia 247: 499-512.

D’Andrea, A., Guermandi, M.P. (eds.), 2008. Strumenti per l'archeologia preventiva: esperienze, normative e tecnologie, Budapest: Archaeolingua.

De Caro, S. 2008, “Archeologia preventiva, lo stato della materia,” in Strumenti per l'archeologia preventiva: esperienze, normative e tecnologie, edited by A. D'Andrea and M. P. Guermandi, 11-19. Budapest: Archaeolingua.

Fabretti, R. 1680. De aquis et aquaeductibus veteris Romae dissertationes tres. Rome: typis Ioannis Baptistae Bussotti.

Falzea, F. 2012, Contratti di sponsorizzazione e accordi di collaborazione:innovative figure contrattuali in tema di opere pubbliche locali e di tutela, restauro e manutenzione dei beni culturali e architettonici, Ph. D. Dissertation, University of Pisa. Availble at: http://etd.adm.unipi.it/t/etd-12072012-203441/.

Fantin, A. 2013 “L’archeologia preventiva nella normativa recente.” Il capitale culturale, VII (2013): 153-164.

Favia P., Volpe G. (eds.) 2009. Atti del V Congresso Nazionale di Archeologia Medievale. Florence: All’Insegna del Giglio.

Ferri, P. G., 2012. La restituzione dei beni culturali: problemi etici e giuridici, document available at: http://www.archeologia.beniculturali.it/index.php?it/215/la-

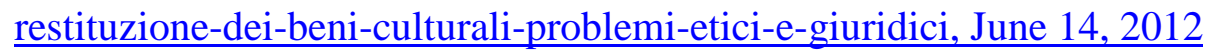


Gamurrini, G.F., Cozza, A. , Pasqui, A. , and Mengarelli, R., 1972. Carta archeologica d'Italia (1881-1897). Materiale per l'Etruria e la Sabina, Firenze

Goethe, J. W., von. 1970. Italian journey. Translated by W. H. Auden and E. Mayer. London: Penguin Books.

Goethe, J. W., von. 1997. Viaggio in Italia. Milano: Garzanti.

Grande Progetto Pompei, 2012. Rome: Gangemi. Document available at: http://www.beniculturali.it/mibac/multimedia/MiBAC/documents/1360253572099_Pompei_br $\underline{\text { ochure.pdf }}$

Guerzoni, G, (ed.), 2012. Le mostre al tempo della crisi. Il sistema espositivo italiano negli anni 2009-2011, A report by Fondazione Florens, Firenze.

Hülsen, C. 1907. La Roma antica di Ciriaco d'Ancona: disegni inediti del secolo XV. Rome.

I Predatori dell'Arte e il Patrimonio ritrovato (Rome, Museo Nazionale Etrusco di Villa Giulia September 29th - December 15th, 2012), Exhibition Catalogue, Rome 2012. Insolera, I. 1971. Roma moderna: un secolo di storia urbanistica. Turin: Einaudi. Io sono cultura 2013. Io sono cultura. L'Italia della Qualità e della bellezza sfida la Crisi, Report 2013 by Fondazione Symbolia and UnionCamere, document availble at: http://www.unioncamere.gov.it/P42A1664C189S123/-Io-sono-cultura---l-Italia-della-qualitae-della-bellezza-sfida-la-crisi----Rapporto-2013.htm

La felicità di un ritorno. Arma dei Carabinieri, Guardia di Finanza e Polizia di Stato, un impegno costante per restituire l'Arte rubata all'Umanità. Recuperare per tramandare, (Rome, Castel Sant'Angelo April $24^{\text {th }}-$ June $_{26^{\text {th }}}$ 2008), Exhibition Catalogue, 2008, Rome: Gangemi. 
La laurea non fa l'archeologo, 1993. Università degli studi di Roma “La Sapienza.” Atti della Tavola Rotonda (Roma 8 maggio 1992). Mantova: Editrice Società Archeologica Padana.

Lamboglia, N. 1950. Gli scavi di Albintimilium e la cronologia della ceramica romana. Parte prima, Campagne di scavo 1938-1940. Bordighera: Istituto Internazionale di Studi Liguri.

Lanciani, R. 1988. Forma Urbis Romae. Rome: Quasar.

Lanciani, R. 1989. Storia degli scavi di Roma e notizie intorno le collezioni romane di antichità. Rome: Quasar.

Ligorio, P. 1553. Libro di M. Pyrrho Ligori napolitano, delle antichità di Roma: nel quale si tratta de'circi, theatri \& anfitheatri: con le paradosse del medesimo auttore, quai confutano la commune opinione sopra vari luoghi della città di Roma. Venice.

Locatelli, D. and L. Malnati. 2009. “Tutela e aspetti legislativi: il ruolo delle Soprintendenze," in Emergenza sostenibile. Metodi e strategie dell'archeologia urbana (Atti della giornata di studi: Bologna, 27 marzo 2009). Edited by M.T. Guaitoli, retrieved June $29^{\text {th }}$ 2013 from http://books.bradypus.net/emergenza_sostenibile/09.

Maggi R. 2007. “The approach to preventive archaeology in Italy”, European Preventive Archaeology (Papers of the EPAC Meeting, Vilnius 2004) edited by K. BozókiErnyey 2007. 147-154. Budapest: Demax.

Malnati, L. 2008, “La verifica preventiva dell’interesse archeologico,” in Strumenti per l'archeologia preventiva: esperienze, normative e tecnologie, edited by A. D’Andrea and M. P. Guermandi, 21-32. Budapest: Archaeolingua. 
Malnati, L. 2011, “La ‘chiamata a raccolta’ degli archeologi”, in Valorizzazione e gestione integrata del patrimonio archeologico (XIV Borsa Mediterranea del Turismo Archeologico, Paestum 17-20 novembre 2011), 8-11.

Manacorda, D. 1982. “Per un’indagine sull’archeologia italiana durante il ventennio fascista.” Archeologia Medievale 9: 443-470.

Manacorda, D. and R. Tamassia. 1985. Il piccone del regime. Rome: Curcio.

Matsuda, A. 2004. The Concept of 'the Public' and the Aims of Public Archaeology. "Papers from the Institute of Archaeology” 15: 66-76.

Minicifre 2013. Culture in Italy, basic figures 2012. Annual Report by MiBAC, Segretariato Generale, Ufficio Studi, Rome: Gangemi. Document available at: http://www.beniculturali.it/mibac/opencms/UfficioStudi/sito-

$\underline{\text { UfficioStudi/MenuPrincipale/Menu-pubblicato/Pubblicazioni/Minicifre-della- }}$ cultura/index.html

Nostoi. Capolavori Ritrovati, (Rome, Palazzo del Quirinale December 21th, 2007 March 2nd, 2008) Exhibition Catalogue, Rome 2007.

Pallottino, M. 1958. “Archeologia.” EAA II: 544-557.

Pallottino, M. 1968. Che cos'è l'archeologia?. Firenze: Sansoni.

Pucci, G. 1993. Il passato prossimo, Rome: La Nuova Italia Scientifica.

Romano, A. 1998. “A trent’anni dal '68. 'Questione universitaria’ e 'riforma universitaria.' Annali di Storia delle Università italiane 2: http://www.cisui.unibo.it/frame_annali.htm

Rowe, J. H. 1965. “The Renaissance Foundations of Anthropology.” American Anthropologist 67: 1-20.

Saioni, M., 2012. “Comunicare l’archeologia. L’esperienza della Soprintendenza per i Beni Archeologici dell’Umbria.” Bollettino di Archeologia On Line III, 2012, 1: 24-32. 
Sassatelli, G. 2011. “Università e formazione,” in Valorizzazione e gestione integrata del patrimonio archeologico (XIV Borsa Mediterranea del Turismo Archeologico, Paestum 17-20 novembre 2011), 12-13.

Settis, S., 2002. Italia S.p.A. L'assalto al patrimonio culturale. Turin: Einaudi.

Solfaroli Camillocci, F. 2013. Che cosa può fare il Fisco per la Cultura. Le agevolazioni fiscali dalla legge 512 del 1982 ad oggi, lecture given at the conference "Tutela del patrimonio artistico nazionale”, Roma, Museo Nazionale Etrusco di Villa Giulia, May 2013. document available at http://www.urfi.it/images/docs/agevfiscmaggio20013.pdf. The same document is edited in “ Il Fisco” 27/2013, fasc. 1.

Tamiozzo, R. 1998. La legislazione dei beni culturali e ambientali. Milano: Giuffrè.

Terrenato, N., “Field Survey Methods in Central Italy (Etruria and Umbria),” in Archaeological Dialogues, 3, 1996, pp. 216-230.

Traffico illecito del Patrimonio Archeologico. Internazionalizzazione del fenomeno e problematiche di contrasto (Proceedings of the 7th international conference, Rome June 25th28th, 2001), “Bollettino di Numismatica”, Suppl. 38, Rome 2002.

UNESCO Report 2013, Joint World Heritage Centre/ICOMOS Reactive Monitoring Mission to Pompei, Hercolaneum and Torre Annunziata (Italy) report, 7-10 January 2013, document available at: http://whc.unesco.org/en/sessions/37COM/documents.

UNESCO WHC 2013, Item 7B of the Provisional Agenda: State of conservation of World Heritage properties inscribed on the World Heritage List, World Heritage Committee, Thirty-seventh session, Phnom Penh, Cambodia, 16 - 27 June 2013, document available at: http://whc.unesco.org/en/sessions/37COM/documents.

Valla, L. 1928. Laurentii Vallae De falso credita et ementita Constantini donatione declamation. Recensuit et apparatu critico instruxit Walther Schwahn. Lipsia: Teubner. 
Vannini, G. 2011. “Presentazione”; “Università e Società, Ricerca e Sviluppo. Verso un’Archeologia Pubblica in Toscana.” In Archeologia Pubblica in Toscana. Un progetto e una proposta, edited by G. Vannini, G., 19-22; 25-33. Florence: Firenze University Press.

Watson, P., Todeschini, C., 2006. The Medici Conspiracy. The Illicit Journey of Looted Antiquities, New York: PublicAffairs.

Winckelmann, J. J. 1767. Geschichte der Kunst des Alterthums. Dresden.

Winckelmann, J. J. 1783-4. Storia delle arti del disegno presso gli antichi. Translated by Carlo Fea. Roma: Stamperia Pagliarini. 